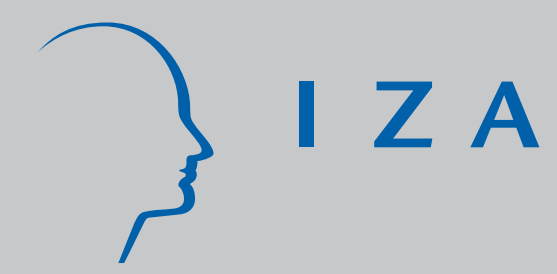

IZA DP No. 892

What Do Unions Do for Economic Performance?

Barry T. Hirsch

October 2003 


\title{
What Do Unions Do for Economic Performance?
}

\author{
Barry T. Hirsch \\ Trinity University and IZA Bonn
}

Discussion Paper No. 892

October 2003

\author{
IZA \\ P.O. Box 7240 \\ D-53072 Bonn \\ Germany \\ Tel.: +49-228-3894-0 \\ Fax: +49-228-3894-210 \\ Email: iza@iza.org
}

This Discussion Paper is issued within the framework of IZA's research area The Future of Labor. Any opinions expressed here are those of the author(s) and not those of the institute. Research disseminated by IZA may include views on policy, but the institute itself takes no institutional policy positions.

The Institute for the Study of Labor (IZA) in Bonn is a local and virtual international research center and a place of communication between science, politics and business. IZA is an independent, nonprofit limited liability company (Gesellschaft mit beschränkter Haftung) supported by Deutsche Post World Net. The center is associated with the University of Bonn and offers a stimulating research environment through its research networks, research support, and visitors and doctoral programs. IZA engages in (i) original and internationally competitive research in all fields of labor economics, (ii) development of policy concepts, and (iii) dissemination of research results and concepts to the interested public. The current research program deals with (1) mobility and flexibility of labor, (2) internationalization of labor markets, (3) welfare state and labor market, (4) labor markets in transition countries, (5) the future of labor, (6) evaluation of labor market policies and projects and (7) general labor economics.

IZA Discussion Papers often represent preliminary work and are circulated to encourage discussion. Citation of such a paper should account for its provisional character. A revised version may be available on the IZA website (www.iza.org) or directly from the author. 
IZA Discussion Paper No. 892

October 2003

\section{ABSTRACT}

\section{What Do Unions Do for Economic Performance?*}

Twenty years have passed since Freeman and Medoff's What Do Unions Do? This essay assesses their analysis of how unions in the U.S. private sector affect economic performance - productivity, profitability, investment, and growth. Freeman and Medoff are clearly correct that union productivity effects vary substantially across workplaces. Their conclusion that union effects are on average positive and substantial cannot be sustained, subsequent evidence suggesting an average union productivity effect near zero. Their speculation that productivity effects are larger in more competitive environments appears to hold up, although more evidence is needed. Subsequent literature continues to find unions associated with lower profitability, as noted by Freeman and Medoff. Unions are found to tax returns stemming from market power, but industry concentration is not the source of such returns. Rather, unions capture firm quasi-rents arising from long-lived tangible and intangible capital and from firm-specific advantages. Lower profits and the union tax on asset returns leads to reduced investment and, subsequently, lower employment and productivity growth. There is little evidence that unionization leads to higher rates of business failure. Given the decline in U.S. private sector unionism, I explore avenues through which individual and collective voice might be enhanced, focusing on labor law and workplace governance defaults. Substantial enhancement of voice requires change in the nonunion sector and employer as well as worker initiatives. It is unclear whether labor unions would be revitalized or further marginalized by such an evolution.

JEL Classification: J5, L1, D2

Keywords: unions, economic performance, productivity, profits, investment, growth, collective voice

Barry T. Hirsch

Department of Economics

Trinity University

San Antonio, TX 78212-7200

USA

Tel.: +1210999 8112

Fax: +12109997255

Email: bhirsch@trinity.edu

\footnotetext{
* Prepared for: James T. Bennett and Bruce E. Kaufman, eds. What Do Unions Do? The Evidence Twenty Years Later, Chapter 6, forthcoming. The paper benefited from the detailed comments of Bruce Kaufman, helpful discussion with John Addison, and editorial suggestions from James Bennett.
} 


\section{Introduction}

The publication in 1984 of Richard Freeman and James Medoff's What Do Unions Do?, which summarized and synthesized results from their broad-based research program, was a landmark in labor economics and industrial relations. What Do Unions Do? quickly changed the subject matter and approach for scholars studying unions. The models (or descriptions) of unions employed by labor economists were extended to include a collective voice face of unions in addition to its microeconomic monopoly face. Empirical analyses of unions, which once focused almost exclusively on union wage effects, began to address the large variety of topics studied in What Do Unions Do? Industrial relations scholars, who had never abandoned a broad multi-disciplinary approach to what unions do, increasingly were expected to include data and econometric analysis in their research.

The appearance of What Do Unions Do? coincided with the beginnings of the long-term decline in private sector unionism in the U.S. Although unionism was declining, the steady stream of research fueled by What Do Unions Do? provided us with a far richer understanding of the nature of unions and collective bargaining than we would otherwise have had. Twenty years later, the approach adopted and empirical regularities found by Freeman and Medoff hold up reasonably well. The continuing decline of private sector unionism, however, eventually eroded interest in and research on this topic. Freeman and other scholars increasingly have turned their attention toward issues such as public sector unions, alternative union and nonunion forms of worker representation, and workplace institutions outside the U.S.

This essay focuses on perhaps the most contentious topic in What Do Unions Do? - union effects on productivity, growth, profits, and investment. Contentious first because the monopoly and voice approaches to unions provide different expectations about union effects on performance, and second because the empirical evidence on which conclusions were based was extremely limited in 1984 (and remains limited today). Much of their story on unions and economic performance holds up well. ${ }^{1}$ Freeman and Medoff rightly emphasize that union effects on productivity vary with respect to the labor relations environment and degree of competition, that unions generally decrease profitability, and that there exists slower growth in the

\footnotetext{
${ }^{1}$ When I refer to Freeman and Medoff's “story" I refer to what the authors actually state in What Do Unions Do? and not to the simplistic (and incorrect) caricature of their work as saying that unions are everywhere good.
} 
union sector of the economy. Subsequent research suggesting that average union productivity effects are close to zero does not support Freeman and Medoff's conclusion that unions are generally good for productivity. Although they conclude that monopoly profits provide the principal source for union wage increases, subsequent research suggests that unions also tax the normal returns to long-lived tangible and intangible capital investments. And while it is true that much of the negative relationship between unions and growth is not causal, slower growth is partly attributable to the lower profits and investment resulting from union rent seeking.

I first summarize what Freeman and Medoff say about unions and performance in What Do Unions Do? A brief section on issues of measurement follows. I then provide an analysis of subsequent evidence on unions and performance, focusing on studies examining the U.S. private sector. This lengthy section is not intended to provide an exhaustive survey of each topic but, rather, to evaluate the themes, evidence, and conclusions presented in What Do Unions Do? $?^{2}$ The next section is rather speculative, looking forward and asking what types of policy changes might better encourage workplace voice and participation in a world of declining unionism. A concluding section follows.

\section{What Do Freeman and Medoff Do?}

Freeman and Medoff examine the effects of unions on firm performance in two chapters of What Do Unions Do? Chapter 11 asks whether unionism is good or bad for productivity. Chapter 12 provides evidence on unions and profitability. They rightly emphasize that: "What unions do to productivity is one of the key factors in assessing the overall economic impact of unions" (p. 180). They conclude that in general unions tend to increase productivity, although the effect varies to no small extent with respect to time and place and the associated labor relations environment. In contrast, unionism almost always lowers profitability. Taken together, these pieces of evidence present a paradox. In Freeman and Medoff's words: "Beneficial to organized workers, almost always; beneficial to the economy, in many ways; but harmful to the bottom line of company balance sheets: this is the paradox of American trade unionism, which underlies some of the ambivalence of our national policies toward the institution" (p. 190).

\footnotetext{
2 There have been numerous surveys or appraisals of unions and performance in the U.S. and in other countries; see, for example, Becker and Olson (1987), Addison and Hirsch (1989), Booth (1995), Belman (1992), Freeman (1992), Kuhn (1998), Hirsch (1997), Doucouliagos and Laroche (2003), Aidt and Tzannatos (2002), Metcalf (2003), and Van Reenen and Menezes-Filho (2003).
} 
Freeman and Medoff identify three routes through which unions affect productivity. One is via price-theoretic effects from standard microeconomic theory. Given union monopoly wage gains, firms may shift toward more capital and higher quality labor. As discussed later, a union wage gain need not produce such responses, but this point can be ignored for now. Although capital deepening or skill upgrading increase output per hour, this is not what is being tested (in principle) in the unions-productivity literature. Rather, the thesis is that unions increase "technical efficiency" - output for a given mix of inputs. Empirical literature in this area is clear on the issue, attempting to quantitatively control for capital investment and labor quality. If unions affect output per worker exclusively by moving up a labor demand schedule, then such price-theoretic responses should not show up as union productivity gains in the empirical estimates. ${ }^{3}$

As outlined by Freeman and Medoff, what should show up in the empirical literature (which controls for the input mix) is the net effect of restrictive union work rules and voice/response interaction, the former depressing and latter raising productivity (1984, figure 11-1, p. 163). These categories should be interpreted broadly. "Restrictive work rules" can include not only inefficient staffing requirements ("featherbedding"), but also any decrease in productivity resulting from limited incentives for worker effort or restrictions on management discretion (obviously, union formalization of the workplace governance structure can increase or decrease productivity). ${ }^{4}$ As for voice/response, Freeman and Medoff highlight lower quits and improved personnel policies as key to increased productivity, emphasizing that positive outcomes require good labor relations. Productivity enhancing institutional response might also include a "shock effect" to management induced by higher union wages. Whether such a response should be considered a union voice/response effect or a monopoly effect is not clear, raising the more fundamental question as to whether the two faces of unions are truly distinct. I return briefly to this question later. Given both positive and negative effects, the net effect of unions on productivity is an empirical question.

Empirical evidence on unions and productivity was rather sketchy in 1984; it remains less than clearcut today. As Freeman and Medoff state: "This 'answer' to the debate over what unions do to productivity is

\footnotetext{
${ }^{3}$ Addison and Hirsch (1989) make this point, largely rejecting the critique of Brown and Medoff (1978) made by Reynolds (1986).

${ }^{4}$ More broadly, what shows up using the production function approach are the effects of any factor (not elsewhere controlled for) affecting productivity and correlated with unionism. For example, the impact of union pay compression, which can positively or negatively affect productivity, would be included in estimated union productivity effects.
} 
probably the most controversial and least widely accepted result in this book" (1984, p. 180). Freeman and Medoff summarize evidence on manufacturing studies and sector-specific studies in construction, wooden furniture, cement, and coal (1984, Table 11-1, p. 166). The strongest evidence for a large positive effect of unions on productivity comes from Brown and Medoff's (1978) rightly influential study using manufacturing industry-by-state data. Depending on one's assumption regarding capital usage, one obtains estimates of union effects on total factor productivity of either 20-25 percent or 10-15 percent. Additional unpublished work with Jonathan Leonard using 1972 and 1977 Census of Manufacturers data produces positive estimates of union productivity effects.

In contrast to the Brown and Medoff study, Clark's (1984) analysis of manufacturing lines of business indicated a -2 percent average difference in the productivity of union and nonunion businesses. Freeman and Medoff cite but do not emphasize Clark's results, despite the fact that business-level analysis has numerous advantages over Brown and Medoff's highly aggregated data.

Sector-specific studies using value-added measures of output during the 1970s indicate extremely large union productivity effects in construction and moderate productivity effects in wooden household furniture. Studies using physical output measures confirm large union productivity effects in construction. Clark's studies of cement plants indicate a moderate union productivity advantage (6-8 percent) in his crosssectional analysis and a roughly similar increase in productivity among the relatively few plants changing from nonunion to union status. Among the more interesting results in Freeman and Medoff's table are productivity results in underground bituminous coal for four years, 1965, 1970, 1975, and 1980, with union productivity effects swinging from highly positive in 1965 to highly negative in 1975 and 1980 . Freeman and Medoff link these changes to deterioration in labor relations within the industry, emphasizing that union effects in the workplace vary depending on labor and management policies and their working relationship.

Despite the rather mixed empirical evidence on productivity, even in 1984, Freeman and Medoff interpret these findings as follows: "In sum, most studies of productivity find that unionized establishments are more productive than otherwise comparable nonunion establishments" (1984, p. 169).

Freeman and Medoff recognize the importance of union effects on productivity growth as well as levels. They analyze three alternative data sets, in each case finding industry union density associated with 
slower productivity growth. The magnitude of the estimates is nontrivial (relative to mean growth rates), but none is statistically significant, reflecting the large variation across industries in growth rates and their relationship to unionism. Freeman and Medoff conclude: "In sum, current empirical evidence offers little support for the assertion that unionization is associated with lower (or higher) productivity advance" (p. 170).

The final sections of Chapter 11 explore why or how unions affect productivity. There is no single metric to be estimated here; rather the authors assemble various observations or findings across otherwise disparate studies. Each of their explanations fits into their collective voice/institutional response framework, although in different ways. They first give prominence to the Brown and Medoff (1978) estimate that onefifth of the union productivity effect found in their study can be attributed to lower quit rates. They also emphasize Clark's (1980a) findings that cement plants switching from nonunion to union changed their plant managers, replacing previously authoritarian or paternalistic managerial practices with more professional and structured supervision and governance. Freeman and Medoff next cite studies showing a link between productivity at unionized plants and the industrial relations climate in those plants, as reflected in number of grievances. Returning to the coal industry, where productivity swung from positive to negative, Freeman and Medoff state (italics in original): "The lesson is that unionism per se is neither a plus nor a minus to productivity. What matters is how unions and management interact at the workplace" (p. 179). They then note the importance of competition, suggesting that the coal industry's deterioration in labor relations and failure to maintain productivity gains along with wage gains stems in part from limited competition in that sector. In the concluding section of their productivity chapter, the authors declare: "Higher productivity appears to run hand in hand with good industrial relations and to be spurred by competition in the product market, while lower productivity under unionism appears to exist under the opposite circumstances" (p. 180). Chapter 12, entitled "But Unionism Lowers Profits," summarizes what at the time was very limited evidence on unions and profitability. Freeman and Medoff (1984, Table 12-1, p. 183) rely on their own unpublished work using aggregate industry data from the Census of Manufacturers or from the Internal Revenue Service, as well as line-of-business data subsequently published in Clark's (1984) paper. Clark's study finds that union plants realize a price-cost margin 16 percent lower than nonunion plants, and "quasirents divided by capital" 19 percent lower. The aggregate data likewise indicated substantially lower profits 
associated with unionism, but with a wider range of estimates. The authors also cite Ruback and Zimmerman's (1984) subsequently published study showing that stock values fall as a result of successful union organizing drives. Despite the paucity of data on profitability, they conclude that unions lower profits. Subsequent work fully supports this conclusion.

Evidence is less clear as to whose profits are hardest hit. Freeman and Medoff emphasize work using aggregate industry data showing that unions reduce profits substantially in highly concentrated industries, but not in low-concentration industries. They also cite a subsequently published paper by Salinger (1984) arriving at the same conclusion using company data (although concentration is only weakly related to market value in Salinger's study). As discussed below, Salinger's conclusion is based on a restrictive specification that forces the union profit effect to interact with concentration and other variables (Hirsch and Connolly, 1987). Freeman and Medoff downplay Clark's (1984) finding that the largest impact of unions on profits is among lines of business with low market shares, noting in a footnote Clark's "contrary result ... limited to a special group of businesses rather than to the entire economy" (1984, p. 278, fn. 7). Freeman and Medoff conclude that "the union profit effect appears to take the form of a reduction of monopoly profits" (1984, p. 186). Freeman and Medoff, however, are quick to point out that lower profits, whatever their source, can be associated with lower investment and growth. They explore the relationship between concentration and growth, find conflicting evidence, and safely conclude that the evidence relating unions, profitability, concentration, and growth is mixed. They rightly recognize "an important point about the impact of unions on profits: there is little normative content in the direction of the effect per se; rather, what matter are the market conditions and routes by which unionism alters profits" (p. 189).

In summary, Freeman and Medoff conclude that "the evidence on profitability shows that, on average, unionism is harmful to the financial well-being of organized enterprises or sectors" (p. 190). Beneficial to organized workers but harmful to the bottom line of companies - this paradox of American labor unions is one that Freeman and Medoff fully recognize. I return to this point subsequently.

\section{Two Faces Revisited: What Does Theory Do?}

By the time that What Do Unions Do? was published in 1984, Freeman and Medoff's "two faces of unions" dichotomy (Freeman and Medoff, 1979; Freeman, 1980) had become a standard framework or cataloging 
device to address the labor market effects of unions and remains so twenty years later. Although not a formal model in the sense that economists typically use the term, the two-faces approach has provided a broad umbrella under which labor economists and industrial relations scholars either have organized their thoughts about what unions do or, less frequently, based their explicit theoretical models of union behavior. The beauty of the framework is that the two faces - monopoly and voice - provide a sufficiently accurate description or shorthand for unions' principal activities, while at the same time being sufficiently broad to permit inclusion of a wide range of union effects in the workplace and economy.

The monopoly-voice distinction is not without limitations, however; the most serious is that these categories are neither distinct nor without ambiguity. Three examples should suffice. First, worker preferences and demand for wages, benefits, employment security, and working conditions depend in no small part on union bargaining power. Is this union's voice or monopoly face? Second, Freeman and Medoff stress that workplace outcomes depend crucially on management's response to its union. Is tighter management control in response to a union wage increases (a "shock effect") an example of labor union's voice/response or monopoly face? Or should one speak of a monopoly/response face? Finally, surveys indicate that workers have a desire for greater voice and cooperation in the workplace (Freeman and Rogers, 1999). Should this be considered an unsatisfied demand for union representation and the types of collective voice/response associated with unions? Or is it instead a desire for forms of individual voice and workplace interaction more typically found in nonunion than in union establishments (Kaufman, 2001)?

To address such questions, it is necessary to delineate a much clearer theory of what unions do. Fortunately, such an endeavor is not essential for this essay (but see the contribution to this symposium by Addison and Belfield on union voice). Herein, it is sufficient to identify those elements associated with unions that are likely to improve or detract from productivity, growth, profits, and investment. The monopoly/voice framework is a useful device to organize parts of the discussion. Once the focus turns to empirical evidence, one typically identifies (at best) the net effect of unions on various outcomes and rarely identifies the specific routes at work. 
The monopoly face typically refers to what are mostly negative results emanating from union distortions relative to what might otherwise exist in a competitive labor market. ${ }^{5}$ This face emphasizes the role of bargaining power, recognizing that the ability of unions to extract monopoly gains for its members is determined by the degree of competition and constraints on substitution facing both the employer and union. The standard microeconomic model has unions affecting labor (and product) market outcomes via wages above opportunity costs. The wage premium distorts relative factor prices and factor usage, thus producing a (presumably small) deadweight welfare loss. Independent of price distortions, unions may cause losses in output through strikes and decrease productivity in some workplaces through contractual work rules, reduced worker incentives, and limited managerial discretion.

Taken more broadly, the monopoly face can catalog any union effect that decreases efficiency or total value (the "size of the pie") to firm stakeholders (workers and owners) and consumers. Literature since What Do Unions Do? emphasizes unions' role in taxing returns on tangible and intangible capital and the resulting effects on profitability, investment, and growth.

The other face of unions is what Freeman and Medoff call "collective voice/institutional response." This face focuses on value-enhancing aspects of unions, emphasizing the potential role that collective bargaining has in improving the functioning of internal labor markets. For example, legally protected unions can effectively allow workers to express their preferences and exercise "collective voice" in the shaping of internal industrial relations policies. Collective bargaining may be more effective than individual bargaining or regulation in overcoming workplace public-goods problems and attendant free-rider problems. As the workers' agent, unions may facilitate the exercise of the workers' right to free speech, acquire information, monitor employer behavior, and formalize the workplace governance structure (Weil, 2003). Unions may better represent average or inframarginal workers, as opposed to workers who are most mobile and hired at the margin. In some settings, the exercise of collective voice should be associated with higher workplace productivity, an outcome that depends not only on effective voice, but also on a constructive "institutional

\footnotetext{
${ }^{5}$ Recent literature (Manning, 2003) argues that many firms face upward sloping supply curves (i.e., have a work force with limited mobility) and thus have leeway in their choice of wage policies. Unlike classical monoponsy theory, the "new monopsony" literature downplays the importance of market structure and provides few implications about employment and efficiency (just as price discrimination does not have clear-cut implications for output and efficiency). A principal outcome of new monopsony is wage heterogeneity. It is not clear if this literature has a lot to say about union performance outcomes, apart from the obvious point that the nonunion counterfactual is more complex than a textbook competitive labor market. The empirical importance of the new monopsony literature remains to be seen.
} 
response" and a cooperative labor relations environment. Freeman and Medoff emphasize that supportive management response to union voice is a necessary condition for positive union outcomes. Less clear is whether management actions that produce positive outcomes are responses to union voice (or voice bolstered by bargaining power) or responses to monopoly gains.

The monopoly and voice faces of unionism operate side-by-side, the importance of each being influenced by the economic environment. For a union firm in a reasonably competitive, largely nonunion industry, cost increases cannot be passed forward to consumers through higher prices. Thus, absent a productivity offset, unions should have little bargaining strength. Substantial union wage premiums in a competitive setting absent productivity improvements should lead establishments to contract over time. If a sizable proportion of an industry is unionized, industry-wide wage increases absent productivity offsets increase costs throughout the industry, costs increases are passed through to consumers, and no individual firm is at a severe disadvantage. But such a tuation is difficult to sustain in the long run, if entry/expansion of nonunion companies is possible or products are tradeable in world markets. On the one hand, the more competitive the market, the more limited is unions' bargaining power and ability to organize. On the other hand, the more competitive the market the greater the pressure on union companies to increase productivity. From a measurement standpoint, union companies that prosper or survive in a competitive environment are not a random draw from among all possible (and largely unobserved) union-firm experiences.

Unions have considerably greater ability to organize and to acquire and maintain wage gains in less competitive economic settings. Such settings include regulated industries in which entry and rate competition is legally restricted and oligopolistic industries in which entry is difficult because of economies of scale or limited international competition. Examples of the former include the previously regulated U.S. trucking and airline industries and the currently protected U.S. Postal Service, in each of which unionized workers have captured regulatory rents (Hirsch, 1988; Hirsch and Macpherson, 1998; Hirsch, et al., 1999). Examples of the latter include the deregulated airline industry and the automobile industry. Following deregulation, unions' considerable strike power in the airline industry was maintained, allowing unions to capture a sizable share of potential profits during periods of strong demand but requiring concessions during downturns (Hirsch and Macpherson, 2000). In the automotive industry, labor relations have adapted in 
response to more limited market power and union power following the influx of European and Japanese imports, foreign-owned nonunion assembly plants in the U.S., and labor-saving technological change and production innovations (Katz and MacDuffie, 1994).

Absent an offsetting productivity effect, a critical question concerns the source from which a union premium derives. Were it entirely a tax on economic profits (returns above opportunity costs), union rent seeking might be relatively benign. But for most firms in a competitive economy, above-normal returns are relatively small and short-lived. What appear to be abnormally high profits often represent the reward to firms for developing new and successful products, a reward for implementing cost-reducing production processes, or simply the quasi-rents that represent the normal returns to prior investment in long-lived physical and R\&D capital. These profits serve an important economic role, providing incentive for investment and attracting resources into those economic activities most highly valued. To the extent that union gains vary directly with the quasi-rents emanating from long-lived capital, union wage increases can be viewed as a tax on capital that lowers the net rate of return on investment. In response, union firms reduce investment in physical and innovative capital, leading to slower growth in sales and employment and shrinkage of the union sector (Baldwin, 1983; Grout, 1984). It no longer follows that capital-labor substitution in union workplaces is optimal, a subject discussed more fully in the section on investment. ${ }^{6}$ Skill upgrading has been a conventional argument in the union literature (Freeman and Medoff, 1984; Lewis, 1986; Hirsch and Addison, 1986). The argument is simple - a union wage premium both allows and provides incentive for employers to upgrade the skill level of their work forces, offsetting part of the higher wage. Yet empirical evidence for skill upgrading is weak. Absence of clear-cut evidence is not surprising, however, once one realizes that such behavior need not follow from theory. Wessels (1994) provides a simple but persuasive challenge to the skill-upgrading hypothesis. If firms upgrade in response to a union wage increase, the union can then bargain in a future contract for an even higher wage in order to restore the premium. Employers, anticipating this, may respond by not upgrading. Firms that upgrade will

\footnotetext{
${ }^{6}$ Using standard theory, a wage gain can decrease capital if scale effects exceed substitution effects, but the capitallabor ratio unambiguously rises. If unions tax capital (i.e., the returns on capital facilitate wage gains), there is no presumption that the factor mix is either more or less capital intensive in union firms (Hirsch and Prasad, 1995). No distortion in the factor mix also follows from bargaining models with "strong efficiency" outcomes (a vertical contract curve). Empirical tests of contract models are particularly difficult (Farber, 1986; Abowd, 1989; Pencavel, 1991).
} 
face higher future wage demands and will have distorted their factor mix, using a higher skill labor mix than is optimal given its technology. Wessels provides an explicit model in which it is assumed that labor quality augments capital productivity and the decision to hire higher (lower) skill workers results if the elasticity of substitution between labor and capital is greater (less) than unity. Wessels concludes that available evidence is not consistent with skill upgrading.

Longitudinal evidence from wage equations also suggests that skill upgrading is not important. Freeman (1986) and Card (1996) conclude that wage-level and change estimates of the union-nonunion wage gap are similar, once one adjusts for bias from measurement error in union status (which is exacerbated in longitudinal estimates). This implies that, on average, unmeasured skills do not differ substantially for union and nonunion workers. Were skill upgrading important, we should observe high measured and unmeasured skills among union as compared to nonunion workers. The selection mechanism within union companies might better be characterized as a form of two-sided selection with positive selection among those with low measured skills and negative selection among those with high measured skills (Abowd and Farber, 1982; Card, 1996). Because of a queue of workers for union jobs, employers are able to avoid hiring workers in the lower tail of the skill distribution (skill here is defined broadly to include productivity-related attributes such as motivation and reliability). Yet few workers from the upper-tail of the skill distribution are either in or chosen from the union queue. Wage compression within union firms, both compression in skill differentials and contractually standardized wages, discourages applications by many of the most able workers. And following the logic of Wessels, firms may not have incentive to screen for and select the most able workers in the union queue if such action may lead to an increase in future wage demands. Card (1996) and Hirsch and Schumacher (1998) find clear evidence of two-sided selection.

The lack of strong longitudinal evidence for high unmeasured skills among union workers provides indirect evidence on unions and productivity. Were there a substantial positive union productivity effect (with measured worker skills and other inputs controlled for), then it seems likely that some of this higher productivity would be reflected in high unmeasured skills among union workers. We see no such thing. It seems implausible that union productivity effects would be embedded entirely in the workplace environment and not at all in workers, although such an outcome would be compatible with the collective voice view of 
how unions affect the workplace.

As the above discussion indicates, evidence is required to assess the relative importance of the monopoly and collective voice faces of unionism. Two additional points warrant emphasis. First, the effects of unions on productivity and other aspects of performance should differ substantially across industries, time, and countries. This is hardly surprising given that both the collective voice and monopoly activities of unions depend crucially on the labor relations and economic environment. Second, union effects are typically measured by differences in performance between union and nonunion firms or sectors. Such differences do not measure the effects of unions on aggregate or economy-wide economic performance as long as resources are free to move across sectors. For example, evidence presented below indicates that union companies in the U.S. have performed poorly relative to nonunion companies. To the extent that output and resources are mobile, poor union performance has led to a shift of production and employment away from unionized industries, firms, and plants and into the nonunion sector. Overall effects on economywide performance have been relatively minor.

\section{Measurement: The Binding Limitations of Data and Inference}

What unions do is largely an empirical question. The evidence on this topic has greatly enhanced our knowledge and understanding of union effects on performance. But the availability and quality of data leave much to be desired. Even were better data available, identifying causal relationships is difficult. In this section, a few of the inherent problems associated with empirical studies are reviewed. My purpose is not to denigrate the value of this work - we would have far less understanding of what unions do absent such evidence. But given present limitations, caution must be used in drawing inferences. Were it possible to analyze these issues using better data and alternative methods, our assessment of how unions affect economic performance would require modification, certainly quantitatively if not qualitatively.

Most studies utilize cross-sectional data (at single or multiple points in time), measuring differences in outcomes (productivity, profitability, etc.) across establishments, firms, or industries with different levels of union coverage. Regression estimates from production functions, profit equations, and the like provide estimates of union-nonunion differences in performance, controlling for other measurable determinants. The 
key question is whether one can conclude that the estimated difference in performance associated with differences in unionization truly represents the causal effect of unions. ${ }^{7}$

There are several reasons why one must exhibit caution in drawing such a conclusion. First is potential bias from omitted variables. If one fails to control for an important productivity determinant and that factor is correlated with union density, then one obtains a biased estimate of the causal effect of unionism on performance. For example, older plants tend to have lower productivity, and union density is higher in older plants. If a study were to estimate the union impact on productivity among plants, the inability to measure and control for plant age (or its correlates, such as age of capital) would mean that part of the effect of plant age on productivity would be included in the (biased) estimate of the effect of unions upon productivity. Of course, omitted variables always exist in empirical work. One should have concern only where theory and supplemental evidence strongly suggest that there may exist substantial bias owing to some specified omission.

A second concern is bias resulting from union status being endogenous, rather than determined randomly (or independently of other correlates of the outcome measure). For example, unions likely will organize and survive in firms (or industries) with high potential profits; in this case, standard estimates of union effects on profitability (typically negative) would understate the impact of unions on profits.

Alternative methods exist to deal with selection, but generally require identification (and measurement) of at least one variable that affects union status (say, state differences in labor law or sentiment toward unions), but not the outcome variable of interest (e.g., profitability).

A third reason for caution in making inferences is concern about "external validity." Even where one has obtained "internal validity" - unbiased estimates of union effects for the population being studied (e.g., a particular industry, time period, or country) - it is not clear whether these results have external validity that permit generalization. The most reliable estimates of union effects on productivity may well be based on specific industries (e.g., cement, sawmills) where output is homogeneous and can be measured in physical units rather than by value added. Yet it is not clear to what extent results in, say, the western

\footnotetext{
${ }^{7}$ I provide no discussion of experimental methods, which have so far played little role in the literature on unions and performance. The experimental literature in personnel economics has added much to our knowledge about how workers perceive and respond to alternative compensation schemes and workplace policies. Such results have potential to inform discussion of how unions impact the workplace, getting inside the proverbial black box.
} 
sawmill industry (Mitchell and Stone, 1992) can be generalized to the economy as a whole, particularly given that we expect union effects to differ across time, establishment, industry, and country.

Several studies combine cross-sectional and longitudinal (i.e., time-series) analysis, typically examining changes in performance over time resulting from to changes in union status (or, similarly, controlling for establishment fixed effects). For example, several studies examine changes in firm market value (measured by stock price changes), investment, or employment following the announcement of union representation elections and their outcomes. A limited number of studies examine changes in productivity or other performance measures following changes in unionization within plants. The advantage of longitudinal analysis is that each individual firm (or plant) forms its own control group - that is, a firm's performance once unionized is compared to its performance prior to unionization (as compared to changes among firms not changing union status). In this way, unmeasured, observation-specific, attributes fixed over time are controlled for in estimating the causal effect of unionization. Although such studies have strong advantages, inference can be difficult. Because unions may affect performance gradually over time, it is difficult to correctly correlate changes in unionization and changes in performance. ${ }^{8}$ Moreover, firms or establishments changing union status are not randomly determined, making it unclear whether or not the measured effect among those receiving "treatment" (union status change) can be generalized to those not treated.

\section{What Have Unions Done? Revisiting the Evidence ${ }^{9}$}

As described in the previous section, union effects on performance must be estimated using imperfect data and statistical models and techniques that permit alternative interpretations of the evidence. Because of these limitations, one must carefully assess individual studies and the cumulative evidence before drawing strong inferences regarding unions' causal effect on performance. Even where the evidence is reasonably compelling, we often know little about the precise mechanisms through which these results are produced. In most of the studies reviewed below, unionization is treated as exogenous and we have little or no information on differences across unions in behavior or strategy. We can estimate the strength of the relationship between union status and productivity, profits, investment, or other performance outcomes. But we do not

\footnotetext{
${ }^{8}$ This criticism does not apply to events studies measuring changes in equity value, since changes in stock price quickly reflect investors' expectations as to the present value of future changes due to unionism. A separate question is whether investors are good at predicting how unionization will affect firm performance.

${ }^{9}$ Portions of this section rely on my earlier survey of unions and performance (Hirsch, 1997).
} 
learn much else. The industrial relations and human resources literature has shed a bit of light inside the union-performance black box. But the literature provides few answers to the types of questions asked by unions regarding appropriate strategies, by management about personnel policies, or by policy makers about appropriate legislative and regulatory reforms. ${ }^{10}$

Discussion herein is largely restricted to the U.S. private sector, as in What Do Unions Do? There is growing international evidence on unions and performance (recent surveys include Aidt and Tzannatos, 2002; Metcalf, 2003; and, tangentially, Nickell and Layard, 1999). It is doubtful that results from other economies can be readily generalized to the U.S., or vice-versa. As we have seen, the effects of unions are specific to the economic, legal, and structural environment. The institution of collective bargaining differs substantially across countries, making comparison difficult (the exception may be Canada and the U.S.). And changes in the economic, legal, and institutional structure surrounding collective bargaining have real effects on outcomes, as seen most notably by the changes in the U.K. since 1980 (Addison and Siebert, 2003; Pencavel, 2003). By the same token, variation across countries in the collective bargaining environment and in the legal structure, if clearly correlated with differences in union effects on performance, can offer clues as to the specific routes through which unions affect the workplace, something lacking in much of the U.S. literature. And non-U.S. studies frequently offer superior data. This is hardly surprising, given that in the U.S. data on firm or plant union density are not publicly available in any systematic fashion. Research may well provide more reliable answers to the question "what do unions do?" for other countries than for the U.S. Productivity and Productivity Growth. Freeman and Medoff rightly emphasize the importance of what unions do to productivity. If collective bargaining in the workplace were systematically to increase productivity and not to retard growth, a strong argument could be made for policies that facilitate union organizing (this statement assumes that union-induced distortions in factor mix and economy-wide resource allocation are minor). A pathbreaking empirical study by Brown and Medoff (1978), followed by the body of evidence summarized in What Do Unions Do?, made for what appeared to many a persuasive case that collective bargaining in the U.S. is, on average, associated with substantial improvements in productivity.

\footnotetext{
${ }^{10}$ In a paper on "what unions do now" Turnbull (2003) makes this point forcefully, arguing for increased multidisciplinary research on unions and the need for greater relevance.
} 
The thesis that unions substantially increase productivity has not held up well. Subsequent studies are as likely to find negative as positive union effects on productivity. Critics have pointed out that a large union enhancement of productivity is inconsistent with the far less controversial evidence on profitability and employment (Addison and Hirsch, 1989; Wessels, 1985). And attention has focused on the dynamic effect of unions and their apparently negative effects on growth in productivity, sales, and employment. Surveys of the unions-productivity literature for the most part have concluded that union effects are highly variable but on average close to zero (see endnote 2). A "meta-analysis" of the unions-productivity literature concludes similarly that the average effect in the U.S. is very small but positive, while negative in the U.K. (Doucouliagos and Laroche, 2003). A survey of labor economists at leading universities asking for an assessment of the union effect on productivity produced a median response of zero and mean of 3.1 percent (Fuchs et al., 1998). ${ }^{11}$

A typical productivity study estimates Cobb-Douglas or (less restrictive) translog production functions in which measured outputs are related to inputs. To fix the discussion, a variant of the CobbDouglas production function developed by Brown and Medoff (1978) is:

$$
Q=A K^{\alpha}\left(L_{n}+c L_{u}\right)^{1-\alpha},
$$

where $Q$ is output; $K$ is capital, $L_{u}$ and $L_{n}$ are union and nonunion labor; $A$ is a constant of proportionality; and $\alpha$ and (1- $\alpha)$ are the output elasticities with respect to capital and labor. The parameter $c$ reflects productivity differences between union and nonunion labor. If $c>1$, union labor is more productive, in line with the collective-voice model; if $c<1$, union labor is less productive, in line with conventional arguments concerning the deleterious impact of such things as union work rules and constraints on merit-based wage dispersion. Manipulation of equation (1) yields the estimating equation

$$
\ln (Q / L) \approx \ln A+\alpha \ln (K / L)+(1-\alpha)(c-1) P,
$$

where $P$ represents proportion unionized $\left(L_{u} / L\right)$ in a firm or industry or the presence or absence of a union at the plant or firm level (a zero/one categorical variable). Equation (2) assumes constant returns to scale, an assumption relaxed by including a $\ln L$ variable as a measure of establishment size. The coefficient on $P$ measures the logarithmic productivity differential of unionized establishments. If it is assumed that the

\footnotetext{
${ }^{11}$ The specific question asked was: "What is your best estimate of the percentage impact of unions on the productivity of unionized companies?" (Fuchs et al., 1998, pp. 1392, 1418).
} 
union effect on productivity solely reflects the differential efficiency of labor inputs, the effect of union labor on productivity is calculated by dividing the coefficient on $P$ by $(1-\alpha)$.

The conclusion that unions in general raise productivity substantially rests almost exclusively on the results of the influential Brown and Medoff (1978) study. Using aggregate two-digit manufacturing industry data cross-classified by state groups for 1972, Brown and Medoff's preferred coefficient estimates on union density are from .22 to .24 , implying values (obtained by dividing the union coefficient by $1-\alpha$ ) for $c-1$ of from .30 to .31 . Using alternative assumptions about capital usage (that increase union relative to nonunion capital), estimates of union productivity effects fall roughly in half. Absent this study, it would have been difficult to sustain the conclusion in What Do Unions Do? that in general unions raise productivity.

Limitations attach to the production function test and to the results in their paper, many of which were identified by Brown and Medoff. The use of value added as an output measure confounds price and quantity effects, since part of the measured union productivity differential may result from higher prices in the unionized sector. Not surprisingly, estimated effects of unions upon productivity tend to be lower when price adjustments are made (Allen, 1986b; Mitchell and Stone, 1992). Union firms can more easily pass through higher costs when they operate in product markets sheltered from nonunion and foreign competition. Use of value added, therefore, is most likely to confound price and output effects in aggregate analyses relating industry value added to industry union density. It is less of a concern in firm or business level analyses that measure firms' union status and industry union density or other industry controls (Clark, 1984; Hirsch, 1991a). These studies tend to find small, generally negative, effects of unions on productivity. It is difficult to reconcile the Brown-Medoff findings with other pieces of evidence. As argued by Addison and Hirsch (1989), parameter estimates from Brown and Medoff would most likely imply an increase in profitability associated with unionism, contrary to the rather unambiguous evidence of lower firm and industry profitability resulting from unionization. Wessels (1985) casts further doubt on these findings by showing that it is difficult to reconcile the productivity and wage evidence in Brown and Medoff with evidence on employment. Offsetting increases in productivity due to unionization and relative labor costs would imply substantial decreases in union employment (holding output constant) if firms shift toward laborsaving capital. Yet unions appear to have little effect on capital-labor ratios (Clark, 1984). 
There are surprisingly few manufacturing-wide or economy-wide productivity studies and, except for Brown and Medoff, none reports consistent evidence of an overall positive effect of unions on productivity. ${ }^{12}$ Clark (1984) provides one of the better broad-based studies. He uses data for 902 manufacturing lines-of-business from 1970 to 1980 to estimate, among other things, value-added (and sales) productivity equations. He obtains marginally significant coefficients on the union variable of from -.02 to -.03. The Clark study has the advantage of a large sample size over multiple years, business-specific information on union coverage, and a detailed set of control variables. In Clark's separate two-digit industry regressions, positive effects by unions on productivity are found only for textiles, furniture, and petroleum. A similar study is conducted by Hirsch (1991a), who examines over 600 publicly-traded manufacturing firms during 1968-1980 (firm union data, collected by the author, is for 1977). Hirsch finds a strong negative relationship between union coverage and firm productivity when including only firm-level control variables, but the union effect drops sharply after including detailed industry controls. The results prove somewhat fragile when subjected to econometric probing. Hirsch interprets his results as providing no evidence for a positive economy-wide productivity effect and weak evidence for a negative effect. As in the Clark study, Hirsch finds considerable variability across industries.

A particularly rich data set has been developed recently by Black and Lynch (2002). They estimate production functions for a large sample of U.S. manufacturing plants over the period 1987-1993. Their study focuses on the effects of various workplace practices, information technology, and management procedures, but union status is also measured and analyzed. Absent interaction terms, Black and Lynch find slightly lower productivity in unionized plants following inclusion of detailed controls, a result equivalent to that in the Clark and Hirsch studies. The authors, however, find that this result is driven by low productivity among

\footnotetext{
${ }^{12}$ I exclude a study by Cooke (1994), who examines data on 841 Michigan manufacturing firms. Cooke's principal focus is on union-nonunion differences in the effect of employee participation programs and profit sharing on productivity. In his sample of firms, union companies have substantially higher output per worker, but Cooke has no measure of firm capital intensity, instead controlling for 2-digit industry capital per employee, which assigns the same capital intensity to union and nonunion firms. Its coefficient is small and barely significant. Prior studies of manufacturing firms or businesses (Clark, 1984; Hirsch, 1991a) find that the capital-labor ratio is the single most important determinant of labor productivity, union firms are somewhat more capital-intensive (unions are more likely to organize successfully in capital-intensive plants), and resulting union-nonunion productivity differences are negative and close to zero. There is little way to know how much of the union-nonunion productivity difference in Cooke's study results from differences in capital intensity; it is unlikely to explain all the difference. The Michigan sample is likely to contain many firms in motor vehicles and transportation supply, an industry where Hirsch (1991) finds union firms to have a large productivity advantage.
} 
unionized plants using traditional management systems. Unionized plants that adopt human resource practices involving joint decision making (i.e., total quality management or TQM) and incentive-based compensation (i.e., profit sharing for nonmanagerial employees) are found to be more productive than their nonunion counterparts, which in turn had higher productivity than union plants using traditional labormanagement relations (Black and Lynch, 2002). These results reinforce the conclusion that union effects are not a given, but depend highly on the specific economic and labor relations environment in which unions operate. Although one is reluctant to put too much emphasis on these specific results, they comport well with our priors. The suggestion is that union plants with high-performance systems, presumably adopted with union agreement, can realize enhanced productivity, whereas traditional top-down managed union plants realize no such enhancement. ${ }^{13}$ Such research reinforces the need to get inside the union black box, helping us understand why there is high variation in performance across different unionized settings. ${ }^{14}$

Productivity studies based on firms within a single industry have advantages as compared to the manufacturing-wide studies. Output can sometimes be measured in physical units rather than value added, information on plant or firm-level union status is more readily available, and more flexible functional forms can be reliably estimated. From a methodological perspective, among the best analyses are Clark's studies of the cement industry (Clark 1980a, 1980b), Allen's analyses of the construction industry (Allen 1986a, 1986b), and Mitchell and Stone's (1992) work on western sawmills. Each of the studies provides a rather wide array of evidence. Clark finds positive, albeit small, effects of unions on productivity among cement plants. Allen (1986b) finds positive union effects in large office building construction and negative effects in school construction. Similarly, Allen (1986a) finds positive and negative union effects on productivity, respectively, in privately and publicly owned hospitals and nursing homes. Mitchell and Stone find negative effects of unions on output in sawmills, following appropriate adjustments for product quality and raw

\footnotetext{
${ }^{13}$ Nickell and Layard (1999) and Metcalf (2003) reach similar conclusions in their evaluation of international evidence. Human resource management (HRM) practices such as TQM do not automatically increase productivity. It appears that the circumstances under which they are adopted make a difference (Kleiner et al., 2002). HRM practices that increase productivity typically increase worker compensation; thus, costs need not decline (Cappelli and Neumark, 2001). ${ }^{14}$ Ichniowski et al. (1997) also examine the effect of HRM practices on productivity. They collect data on steel finishing lines with a common technology but different HRM practices. They conclude that innovative practices increase productivity when introduced jointly (rather than individually). The authors estimate union effects, but say little about these, no doubt due to the paucity of nonunion lines ( 8 percent of the 2,190 line months and what may be just 5 of their 60 steel lines). They obtain union coefficients that are generally small and vary across specifications.
} 
material usage. Although methodological advantages of the industry-specific studies are achieved at the price of a loss in generality, they do increase our understanding of how unions affect the workplace. ${ }^{15}$

Despite substantial diversity in the literature about union productivity, several systematic patterns are revealed (Addison and Hirsch, 1989). First, productivity effects tend to be largest in industries where the union wage premium is most pronounced. This pattern is what critics of the production function test predict - that union density coefficients reflects in part a wage rather than a productivity effect. These results also support a "shock effect" interpretation of unionization, i.e., management responds to an increase in labor costs by organizing more efficiently, reducing slack, and increasing measured productivity. Second, positive union productivity effects are typically largest where competitive pressure exists (consistent with the expectations of Freeman and Medoff, 1984, pp. 179-80), and these positive effects are largely restricted to the private, for-profit, sectors. Notably absent are positive productivity effects in public school construction, public libraries, government bureaus, schools, and law enforcement. ${ }^{16}$

This interpretation of the productivity studies has an interesting twist. The suggestion is that a relatively competitive, cost-conscious environment is a necessary condition for a positive effect of unions on productivity, and that managerial response should be stronger the larger the union wage premium. Yet it is precisely in such competitive environments that there should be little managerial slack and the least scope for union organizing and wage gains. This implies that steady-state union density in the U.S. private sector must remain small, absent a general union productivity advantage. By the same token, introduction of unions or the strengthening of other instruments for collective voice into highly competitive sectors of the U.S. economy is unlikely to have large downside risks for economy-wide performance. Although individual firms may fail to be competitive and perform poorly, market pressures should induce other firms and unions to

\footnotetext{
${ }^{15}$ A general point in the literature is that union productivity effects depend on the state of labor relations. Recent studies provide evidence that productivity or quality suffers as a result of strikes and labor unrest. Kleiner et al. (2002) conclude that the productivity effects of strikes and slowdowns at a commercial airline manufacturer are temporary. Using auction data, Mas (2002) finds that construction equipment produced by Caterpillar at its U.S. plants during periods of labor unrest was more likely to be subsequently resold and sold at a deeper discount. Krueger and Mas (2003) find that tire defect rates were particularly high at a Bridgestone/Firestone plant during periods of labor unrest. ${ }^{16}$ See Addison and Hirsch (1989) and Booth (1995) for references (a study not cited is Byrne et al., 1996). There are exceptions to the conclusion regarding productivity effects in non-competitive settings. An analysis of hospitals by Register (1988) finds higher productivity in union than in nonunion hospitals. A recent paper by Ash and Seago (2002) concludes that there are lower rates of heart attack mortality in California among hospitals with union rather than nonunion registered nurses. This conclusion is based in large part on declines in mortality among a relatively small number of hospitals that became unionized during the sample period.
} 
develop labor relations systems providing the voice/response benefits envisaged by Freeman and Medoff. In short, as the U.S. economy has become more competitive over time (White, 2002), we might expect to see more favorable union-productivity outcomes among surviving and newly unionized establishments.

A concern expressed about the production function test is that there might be survivor bias, a form of selection that would bias upward estimates of union performance (Addison and Hirsch, 1989). In workplaces where unions have the most deleterious effects, businesses fail, contract, or grow slowly. Thus, the sample of union establishments sampled at any point in time includes a large proportion of establishments with positive performance outcomes, while those with poor outcomes are underrepresented. ${ }^{17}$ Subsequent evidence indicates that survivor bias is not as serious as once believed. As discussed later, differences in failure rates among union and nonunion establishments and firms (following controls) appear small. If there is no union impact on business failure, survivor bias would arise only through use of weighted regressions, the use of current employment weights giving too large a weight to establishments with good performance (and growing employment) and too little to those with slow growth. Much of the literature uses unweighted regression estimates, however, which should avoid this particular form of bias.

Overall, the evidence produced since What Do Unions Do? suggests that the authors' characterization of union effects on productivity was overly optimistic. Freeman and Medoff were certainly correct that union productivity effects vary across workplaces, in particular with respect to the labor relations environment. They were correct to emphasize the role of management response, although one might just as readily emphasize the role of union response to management initiatives. And they were correct to note the role that a competitive market environment has on productivity outcomes. What appears incorrect is their conclusion that "productivity is generally higher in unionized establishments than in otherwise comparable establishments that are nonunion..." (p. 180). The empirical evidence does not allow one to infer a precise estimate of the average union productivity effect, but my assessment of existing evidence is that the average union effect is very close to zero, and as likely to be somewhat negative as somewhat positive.

\footnotetext{
${ }^{17}$ The logic here is identical to the survivor bias argument in measuring returns to mutual funds. If one measures past returns (over, say, 10 years) of surviving funds (a balanced panel), average performance is relatively favorable. If one measures the average across all funds in each of the 10 years (an unbalanced panel) average performance, which now includes funds that failed, is below the market as a whole (for evidence, see Malkiel, 2003). Even if no funds failed, an upward bias exists if one weights the funds based on current fund assets, since poorly performing funds would have decreased in relative size over time.
} 
Discussion now turns to the effects of unions on the growth in productivity. Productivity growth is typically measured by the change in value added after controlling for changes in factor inputs. Studies examining union effects on growth typically control (when possible) for union-nonunion differences in the accumulation of tangible and intangible capital and other measurable factors of production. Thus, what is being measured is a "direct" effect of unions on growth. Unions may also decrease productivity growth indirectly through their effects on investment and capital accumulation, a topic addressed shortly. Union effects on productivity levels and growth need not be the same. For example, unionization could initially be associated with higher levels of productivity, owing to a "shock effect" or "collective voice," but at the same time retard the rate of growth. In the long run, of course, low rates of productivity growth should produce lower productivity levels relative to comparison firms or industries.

As discussed earlier, Freeman and Medoff (1984) find lower (but not significant) union productivity growth using alternative industry-level data sets. They regard their results as inconclusive. A more comprehensive analysis using firm-level data (thus permitting control for industry effects) is provided by Hirsch (1991a), based on a sample of 531 firms and covering the period from 1968 to 1980. Following an accounting for company size and firm-level changes in labor, physical capital, and R\&D, union firms have substantially lower productivity growth than nonunion firms. Accounting for industry sales growth, energy usage, and trade, however, cuts the estimate of the union effect by more than half. Addition of industry dummies cuts the estimate further, while the remaining effect proves fragile when subjected to econometric probes regarding the error structure. In short, union firms clearly display substantially lower productivity growth than do nonunion firms, but most (if not all) of this difference is associated with effects attributable to industry differences, union firms being located in industries or sectors with slow growth. There exists no strong evidence that unions have a direct effect on productivity growth.

Despite the contentiousness surrounding the effects of unions on productivity and growth, the most comprehensive studies find little effect that can be deemed causal. Results are simply too variable and not particularly robust to econometric probing. Five points surrounding this conclusion are worth emphasizing. First, union firms can be found to have lower productivity and productivity growth absent detailed controls. This is important in and of itself, although it tells us little about unions' causal effects. Second, a small or 
zero impact of unions on productivity is difficult to interpret. Does this mean that the positive and negative effects of unions are each close to zero, or that they simply cancel each other out with each having an important independent effect? Third, economy-wide studies measure the average effects of unions. There is considerable diversity in outcomes across firms and industries, consistent with the considerable emphasis given to the importance of the economic and labor relations environments. Fourth, studies of productivity and productivity growth control for differences in levels or changes in factor-input usage. But unionization is associated with lower rates of investment and accumulation of physical and innovative capital. This indirect route is primarily how we obtain slower growth in sales and employment in the union sectors of the economy. Finally, absence of a large positive union effect on productivity implies that union compensation gains are not offset, implying lower profitability and (typically) lower investment. The most important point to bring away from the productivity evidence may be the absence of a large positive effect due to unions.

Profitability. Absent sufficient productivity enhancements in the workplace or higher prices in product markets, union wage gains decrease profitability. The evidence on productivity does not suggest sufficiently higher productivity to offset higher compensation. Nor is it plausible that higher prices can offset wage increases, apart from regulated industries where prices are administered to approximate average costs. In more competitive settings, where union firms compete with nonunion domestic companies and traded goods, there is little possibility for passing forward higher costs. Lower profits will be seen in current earnings, in measured rates of return on capital, and in lower stock market values of a firm's assets. Ex-ante returns on equity (risk-adjusted) should not differ between union and nonunion companies, since stock prices adjust downward to reflect lower expected earnings (Hirsch and Morgan, 1994).

The responses of firms to differences in costs (union-relateded or otherwise) should in the long run mitigate differences in profitability. These are mitigated through the movement of resources out of union into nonunion sectors - investment in and by union operations decreasing until post-tax (post-union) rates of return are equivalent to nonunion rates of return. Stated alternatively, union coverage will be restricted to economic sectors realizing above-normal, pre-union rates of returns. Because the quasi-rents accruing to long-lived capital may provide a principal source for union gains and complete long-run adjustments occur slowly, however, we are likely to observe differences in profitability as these adjustments take place. 
Consistent with Freeman and Medoff's conclusion in What Do Unions Do?, subsequent evidence points unambiguously to lower profitability among union companies, although studies differ in their conclusions regarding the source of union gains. Lower profits are found using alternative measures of profitability. Studies using aggregate industry data typically employ as their dependent variable the industry price-cost margin (PCM) defined by (Total Revenue - Variable Costs) / Total Revenue - and typically measured by (Value Added - Payroll - Advertising) / Shipments. Line-of-business studies and some firmlevel studies use accounting profit-rate measures: the rate of return on sales, measured by earnings divided by sales, and the rate of return on capital, measured by earnings divided by the value of the capital stock. Firm-level analyses of publicly traded firms (Salinger, 1984; Hirsch, 1991a, 1991b) use market-value measures of profitability, a common measure being Tobin's $q$, defined as a firm's market value divided by the replacement cost of assets. Finally, "events" studies in which changes in market value attributable to votes for union representation or to unanticipated changes in collective bargaining agreements have been examined (Ruback and Zimmerman, 1984; Bronars and Deere, 1990; Abowd, 1989; Olson and Becker, 1990; Becker and Olson, 1992).

The finding of lower profitability from unionization is not only invariant to the profit measure used, but also holds regardless of the time period under study and holds for analyses using industries, firms, or lines-of-business as the observation unit. Although results vary, studies typically obtain estimates suggesting that unioni firms have profits 10 to 20 percent lower than in nonunion firms. Firm-level studies that include large numbers of firm and industry controls tend to obtain the lower estimates. Economists are understandably skeptical that large profit differentials could survive in a competitive economy. Because rates of profit are not typically large, small absolute differences can produce large percentage differences. Whether one believes 10-20 percent differences in profitability can be sustained for "long" period of times depends on the definition of "long" and one's beliefs regarding the competitiveness of the U.S. economy.

Two potential sources of bias that can be identified cause the effects of unionization to be understated. First, profit functions are estimated only for surviving firms, since those for which the effects of unionization are most deleterious may be less likely to remain in the sample. As stated previously, survival rates of firms do not appear to vary substantially with union status, so bias should be minor. Second, one 
expects unions to be more likely to organize where potential profits are higher; hence, the negative effect of unions on profits should be understated if union density is treated as exogenous. In fact, studies that attempt to account for the simultaneous determination of union status and profitability obtain larger estimates of union effects on profits (Voos and Mishel, 1986; Hirsch, 1991a), although such estimates are not precise. Because unionization in most firms was established long ago, however, the correlation between union status and current potential (i.e., nonunion) profits should be weak.

Although there is a consensus that unions decrease profitability, there is no agreement on the source of union wage gains. Influential early studies cited in What Do Unions Do? concluded that monopoly power provides the primary source for union gains, based on evidence that unions reduce profits primarily in highly concentrated industries (Freeman, 1983; Salinger, 1984; Karier, 1985). Subsequent research calls such a result into question. An early paper by Hirsch and Connolly (1987) criticizes this conclusion on several fronts. Market power arises not only from industry concentration, and rents from market power need not be the only source of union gains. Hirsch and Connolly provide firm-level evidence (but with an industry-level union measure) and find that unions gains derive from the returns associated with firm market share (with industry concentration constant), R\&D capital, and weak foreign competition. With data similar to that used by Salinger, Hirsch and Connolly replicate the result from which he concluded that unions capture concentration-related profits. They show that the Salinger outcome is entirely the product of a restrictive specification that forces all union gains to vary with concentration. A more general specification rejects a positive interaction between union density and concentration.

Hirsch and Connolly also argue that if concentration were a major source of union gains, one should see union wage premiums larger for workers in more concentrated industries. Yet wage studies reject this outcome. In short, there is little evidence from either product or labor markets to support the hypothesis that profits associated with industry concentration provide a source for union rents. In a subsequent analysis using a data set with a firm union coverage measure, Hirsch (1990) more clearly rejects the hypothesis that concentration-related profit is a source of union rents.

The conflict in results with respect to concentration is not simply a result of the use of industry-level versus firm-level data. An industry study by Domowitz et al. (1986) finds no difference in union effects on 
profitability with respect to concentration. Likewise, using 1977 4-digit manufacturing-industry data, Chapell et al. (1991) find that unions have similar negative effects on price-cost margins among industries with low, medium, and high concentration. They also find that within concentration categories, unions have a larger effect on the profits of large than small firms.

Note that the studies summarized above do not reject the conclusion that union bargaining power and wage gains derive in part from firm market power. They reject the thesis that concentration-related profits provide a major source for union gains, in part because of the tenuous link between firm profitability and industry concentration (Ravenscraft, 1983). ${ }^{18}$ As discussed above, unions can and do capture rents stemming from sources of limited competition other than concentration, such as limited trade penetration or firm special advantages. Obvious examples of union gains stemming from market power (or specifically, restrictions on entry) include large wage premiums in the unionized U.S. Postal Service and among union workers in the trucking and airline industries under regulation.

Research appearing since What Do Unions Do? suggests that in addition to capturing rents stemming from market power, unions appropriate quasi-rents, in particular those that make up the normal returns to long-lived investments. This has important implications for investment and long-term growth (addressed below). For example, Hirsch (1991a) concludes that unions capture current earnings associated with limited foreign competition, both current and future earnings associated with disequilibrium or growing demand in the firm and industry (sales growth), future earnings emanating from R\&D capital, and current and future quasi-rents emanating from long-lived physical capital (for related evidence, see Cavanaugh, 1998).

An interesting question is the extent to which the poor profit performance of unionized companies during the 1970s and early 1980s helps explain the decline in union membership during the 1980s and beyond. Blanchflower and Freeman (1992) note the unusually high union wage premiums in the U.S. as opposed to other countries (for recent evidence, see Blanchflower, 2003), arguing that this has consequences for employment and membership. Linneman et al. (1990) show that employment declines have been concentrated in the unionized sectors of the economy; nonunion employment has expanded even in highly

\footnotetext{
${ }^{18}$ Using business-level data, Ravenscraft (1983) finds that market share, but not industry concentration, is related to profitability. Following aggregation, he shows that the positive relationship between industry profit measures and concentration derive from the correlation of concentration with mean market share and not concentration per se.
} 
unionized industries (for an update and extension, see Bratsberg and Ragan, 2003). That is, shifts in industry demand and employment are an insufficient explanation for the decline in private sector unionism. The complement of wage evidence linking large union premiums to declines in membership is the evidence summarized in this section on poor profit performance among union companies. A reasonable inference is that profitability differences between union and nonunion firms help explain declining unionization. Hirsch (1991a) finds a negative correlation between firm-level profitability in the late 1970s and subsequent changes in firm union density between 1977 and 1987. But the relationship between the wage premium, profits, and changes in union density is complex, and the verdict is out on how much of the decline in private sector density is related to lower profitability. Although smaller union wage premiums would lessen management response to unionization, they might also weaken the appeal that union representation has to workers.

Investment in Tangible and Intangible Capital. An area of theoretical and empirical research receiving attention since publication of What Do Unions Do? has been the union effect on investment, based on rent-seeking models in which unions appropriate (i.e., tax) the returns from investments in tangible and intangible capital. The theoretical origins for this literature reach back to Simons (1944); influential papers include Baldwin (1983) and Grout (1984). The earliest empirical paper in this literature appears to be Connolly et al. (1986). Rent-seeking models focus on the fact that unions capture some share of the quasirents that make up the normal return to investment in long-lived capital and R\&D. "Rationally myopic" unions (Hirsch, 1991a; 1992b) find it optimal to tax capital when the time horizon of their members is short relative to owners' time horizon for long-lived, nontransferable capital (it need not follow from theory that the union always has the shorter time horizon; see Addison and Chilton, 1998). In response, firms rationally reduce their investment in vulnerable tangible and intangible capital until returns on investment are equalized across the union and nonunion (i.e., taxed and nontaxed) sectors. Contraction of the union sector, it is argued, results from the long-run response by firms to such rent seeking.

As discussed earlier, the union tax or rent-seeking framework both complements and contrasts with the standard economic model of unions. In the standard model, a union wage increase causes a firm to move up and along its labor-demand schedule by decreasing employment, hiring higher quality workers, and increasing the ratio of capital to labor. Capital investment can increase or decrease owing to substitution and 
scale effects working in opposing directions. In the rent-seeking framework, union wage premiums are a tax on the returns to capital. Firms know that if they invest now in long-lived and nontransferable capital, union bargaining power will result in higher future wages. Stated alternatively, wage increases to unions are in part a tax on capital and need not lead firms to shift their factor mix away from labor and toward capital (Hirsch and Prasad 1995; Addison and Chilton, 1996). ${ }^{19}$

Union rent seeking reduces investment not only in physical capital but also in R\&D and other forms of innovative activity (Connolly et al., 1986). The stock of knowledge and improvements in processes and products emanating from $\mathrm{R} \& \mathrm{D}$ are likely to be relatively long-lived and firm specific. To the extent that returns from innovative activity are appropriable, firms will respond to union power by reducing these investments. Collective-bargaining coverage within a company is most likely to reduce investment in product innovations and relatively factor-neutral process innovations, while having ambiguous effects on labor-saving processes. Expenditures in R\&D also tend to signal - or be statistically prior to - investments in physical capital. Therefore, firms reducing long-range plans for physical capital investment in response to unions' rent-seeking behavior are likely to reduce investment in R\&D.

Patents applied for, or granted, are a measure of innovative output emanating from a company's R\&D stock. Unionized companies may be more likely to patent, given their stock of innovation capital, to reduce union rent appropriation (Connolly et al., 1986). Although the patent application process is often costly and reveals trade secrets, patents offer firms opportunity to license product and process innovations and transform what might otherwise be firm-specific innovative capital into general capital, and lessen a union's ability to appropriate the quasi-rents from that capital. ${ }^{20}$

Hirsch (1991a) provides an empirical analysis of union effects on investment, both tangible and intangible capital. He distinguishes between "direct" and "indirect" investment effects of unions. The direct effect, discussed above, stems from the union tax on the returns to long-lived and relation-specific capital,

\footnotetext{
${ }^{19}$ An additional challenge to the standard model comes from the literature on efficient contracts. There are settlements off the labor-demand curve, with lower wages and higher employment, preferred by both the union and management. Efficient contracts require simultaneous bargaining (explicit or implicit) over wages and employment rather than sequential determination (agreement on the wage followed by the firm's choice of employment). If settlements are not on the labor-demand curve, the effect of unions on factor mix cannot be predicted in straightforward fashion (for analysis of these models, see Farber, 1986; Pencavel, 1991).

${ }^{20}$ Using firm-level Compustat data and union data from Hirsch (1991a), Cavanaugh (1996) shows that the deleterious union effects on market value and investment are directly related to the ease with which quasi-rents can be appropriated.
} 
leading firms to decrease investment to equate the marginal post-tax rate of return with the marginal financing cost. The indirect effect of unions on investment arises from the higher financing costs owing to reduced profits (and, thus, reduces internal funding of investment) for union firms. With data for 1968-1980 for approximately 500 publicly traded manufacturing firms and a model with detailed firm and industry controls, including profitability, Hirsch estimates the effect on investment for a typical unionized company compared to a nonunion company. Other things equal, the typical unionized firm has 6 percent lower capital investment than its observationally equivalent nonunion counterpart. Allowing for the profit effect increases the estimate to about 13 percent; that is, about half of the overall union effect is indirect. Hirsch repeats the exercise for intangible capital (annual investments in R\&D), and his findings imply that the average unionized firm has 15 percent lower $\mathrm{R} \& \mathrm{D}$, holding constant profitability and the other determinants. Allowing for the indirect effects induced by lower profitability only modestly raises the estimate. These deleterious union effects on capital investment have been confirmed in subsequent U.S. studies (e.g., Hirsch, 1992; Becker and Olson, 1992; Bronars and Deere, 1993; Bronars et al., 1994; Cavanaugh, 1998). Fallick and Hassett (1999) examine changes in firms' capital investment in response to a union win in a certification election. They find a substantial reduction, likening the effects of a vote for certification to the effects of a 30 percentage point increase in the corporate income tax.

Given reasonable similarities in the Canadian and U.S. collective bargaining systems and economic environment, two studies warrant mention. Consistent with U.S. evidence, Odgers and Betts (1997) conclude that unions significantly reduce investment in physical capital, while Betts et al. (2001) conclude likewise for R\&D. Despite use of industry data (for multiple years), the authors make a convincing case that they have measured causal union effects.

A comparative study of the U.S. and Britain also warrants attention. Menezes-Filho et al. (1998) provide a detailed analysis of the effects of unions on $\mathrm{R} \& \mathrm{D}$, concluding that although unionized establishments invest less in R\&D, in the United Kingdom this is primarily an effect of the industry location and not of unions. They then subject firm-level data from the U.S. (provided by Hirsch) to the same battery of econometric tests to which they subject the British data. They conclude that, unlike the British evidence, the U.S. evidence of a deleterious effect of unionization on R\&D investment is robust. Whereas the union 
tax model applies well to the U.S., the authors speculate that British unions have fewer deleterious effects on R\&D than do American unions owing to more explicit bargaining over employment levels and a preference for longer contracts. A recent survey by Menezes-Filho and Van Reenen (2003) reaffirms this conclusion in the U.S. labor unions appear to substantially decrease R\&D investment, but this same effect is not evident in Britain. The R\&D evidence is consistent with labor market evidence finding far smaller union wage effects in Britain than in the U.S. (Blanchflower and Bryson, 2003).

Employment Growth and Survival. The effect of unions on employment growth and survival is not independent of its effects on productivity, profits, and investment. It would be surprising were lower profits and investment not accompanied by slower growth, and this exactly what the evidence indicates. Linneman et al. (1990) show that much of what has been represented as a "de-industrialization" of America was in fact a de-unionization. Using Current Population Survey data for the 1980s, they show that within narrowly defined manufacturing industries, most displayed increases in nonunion employment while at the same time witnessing substantial decreases in union employment. The rate of decline in union employment is related to the magnitude of the union wage premium. In one of the few studies to examine firm-level employment growth, Leonard (1992) finds that unionized California companies grew at significantly slower rates than did nonunion companies. Dunne and Macpherson (1994) utilize longitudinal plant-level data (grouped by industry-by-size) to show that there are more employment contractions, fewer expansions, and fewer plant "births" in more highly unionized industries. They find that unions have no effect upon plant "deaths," even after controlling for plant size (larger plants are less likely to fail but more likely to be unionized). Freeman and Kleiner (1999) analyze two sets of data, one including insolvent and solvent firms, each with information on union status, and a second on individuals surveyed in the CPS Displaced Worker Surveys. Using the first data set, Freeman and Kleiner conclude that failed firms or lines of business (most lines of business remain in operation following bankruptcy) have similar union density as do solvent firms and lines of business. Using individual data, they find that being a union worker does not lead to a higher probability of permanent job loss from plant closure or business failure.

Two carefully executed studies examine the results of successful NLRB elections. In a study using longitudinal plant-level data, LaLonde et al. (1996) show that employment (and output) decrease following a 
vote in favor of union certification. DiNardo and Lee (2002) examine the causal effect of union elections on the subsequent survival of establishments. Previous literature is hobbled by a paucity of firm- and establishment-level unionization data and concerns about exogeneity. The authors address each of these issues. Combining NLRB election data for 1983-1999 with a matched listing of whether establishments named in the NLRB file continue to exist at that address in May 2001, they compare survival rates for establishments that have just under and just over a $50 \%$ vote in union elections. The authors make a convincing argument that the only important difference between these two sets of establishments is the union vote, so that subsequent differences in survival probabilities are likely to be causal. DiNardo and Lee conclude that the effects of successful union organizing drives on subsequent survival rates (from 1 to 18 years after an election) are negligible. The authors make a persuasive case that the results they find are causal and internally valid. It is less clear to what extent their results generalize to the larger population of existing (or previously existing) union establishments.

In short, the empirical literature finds that U.S. unions are associated with slower employment growth, but exhibit little or no difference in rates of business failure or survival. ${ }^{21}$ These seemingly inconsistent results require explanation. The argument (Freeman and Kleiner, 1999) is that rent-seeking unions are willing to drive enterprises toward the cliff but not over it. ${ }^{22}$ But in an uncertain world, it is implausible that unions will not sometimes miscalculate economic conditions or management actions, resulting in "accidental" business failures in the union sector. An alternative explanation is that because of wage premiums, union firms may have substantial wage flexibility via contract concessions as compared to nonunion firms with close to opportunity cost wages. Thus, nonunion companies are at a disadvantage when

\footnotetext{
${ }^{21}$ Canadian evidence on unions and employment growth appear consistent with that in the U.S. Long (1993) utilizes survey data from a survey of 510 Canadian business establishments in the manufacturing and nonmanufacturing sectors. Union establishments (i.e., establishments with employees covered by collective bargaining agreements) had considerably slower employment growth between 1980 and 1985, although in manufacturing roughly half of the slower growth resulted not from unionism per se but from location in industries showing slower growth (industry effects were not important in the non-manufacturing sector). After accounting for industry controls, firm size, and firm age, union establishments in the manufacturing (nonmanufacturing) sector had growth rates 3.7 (3.9) percent per year below those of nonunion establishments (union employment growth was negative over the period). For European evidence, see the recent paper by Addison et al. (2003) and the literature survey by Metcalf (2004).

${ }^{22}$ In their words: "Unions reduce profits but they do not "destroy the goose that lays the golden egg" (Freeman and Kleiner, 1999, p. 526). Using even more colorful language, Kuhn (1998, p. 1039) states: "Like successful viruses, unions are smart enough not to kill their hosts." Kremer and Olken (2001) apply a formal evolutionary biology model to unions, noting that parasites that kill their hosts do not spread, whereas those that do little harm spread and may evolve to become essential to their hosts. They conclude that unions maximizing the present value of members' wages are likely to be displaced by more moderate unions. Exogenous firm turnover lowers equilibrium union density since unions must work harder (organize more) to stay in place.
} 
they try to cut costs during a prolonged downturn in business. Such wage flexibility may operate only for the minority of union firms at risk for bankruptcy, plant closures, or significant layoffs; the economy-wide evidence indicates that nonunion wages are procyclical but union wages largely acyclic (Grant, 2001).

\section{What Should Unions Do? Assessing the Future of CV/IR and Public Policy}

Freeman and Medoff (1984) expressed considerable concern for the future of labor unions and the exercise of voice in the workplace. It is obvious, twenty years later, that such concern was warranted. By 2002, traditional collective bargaining serves few workers in the U.S. private sector; only 1-in-12 (8.6 percent) are union members and 1-in-11 (9.3 percent) are covered by a collective bargaining agreement (Hirsch and Macpherson, 2003). Given a competitive world, there is good reason to expect private sector unionism to continue its decline and little reason to predict any "spurt" in organizing success (Freeman, 1998). Such a conclusion is reinforced by the research discussed herein. Given lower profitability in union companies and widespread management resistance to unionization, organizing levels are likely to remain below replacement levels (i.e., normal union job loss) (Farber and Western, 2001).

What does the status quo imply? Continuation of current trends means that workers' desire for effective voice, cooperation with supervisors and management, and participation in decision making will remain unrealized for much of the nonunion (and perhaps union) work force. Absent a formal voice mechanism in the workplace, there is likely to be a continued reliance on governmental regulation and mandates, which by many accounts is insufficiently flexible and overly litigious (for analysis, see Addison and Hirsch, 1997). Labor law reforms could improve fairness, mitigate the contentiousness of the union organizing process, and facilitate organizing, thus slowing the decline in union density. ${ }^{23}$ But union representation would remain very much the exception rather than the rule in the private sector. The case for labor law reforms that would substantially enhance organizing is weakened by what on balance appears to be a deleterious impact of unions, in their current form, on long-run economic performance. More

\footnotetext{
${ }^{23}$ Discussion of labor law reforms is beyond the scope of the paper. Among the recommendations proposed by the Dunlop Commission during the mid-1990s were: narrowing the definition of supervisory and managerial workers who are exempt from the NLRA, shortening the time between the call for union elections and conduct of the elections, increased access of workers to union organizers, procedures such as mediation to facilitate newly certified unions to achieve first contracts, and fast injunctive relief against discriminatory action by employers. Estreicher (1996) discusses various labor law reforms intended to facilitate "value-added unionism" in the workplace. He starts from the premise that labor markets are overregulated and that greater freedom of contract would enhance development of preferred labor-management arrangements.
} 
fundamentally, labor unions as they now operate may not be the ideal organizational form to deliver the individual voice and cooperative work environment that workers want. ${ }^{24}$

Perhaps the fundamental problem with our current collective bargaining framework is the tension between a union's role as an agent of workplace democracy and voice and its role in redistributing income from owners (or consumers) to workers (Freeman and Lazear, 1995). A principal goal of labor law reform should be to encourage collective bargaining that enhances voice and cooperation while discouraging rent seeking. I salute any such efforts, but success is unlikely. Reforms that might work in this direction and that might muster sufficient political support are likely to have at most a modest effect on the steady-state level of union density. It is difficult to envision changes in labor law that will substantially change workplace governance for the more than 90 percent of private sector workers not covered by collective bargaining.

Continuation of the status quo appears likely, perhaps coupled with modest reforms in labor law and a growing role for government regulation in the workplace. Although not a preferred outcome, it is hardly a nightmare scenario. More of the same would permit continued economic growth and improvement in workers' standard of living. The economic pie would get larger and competition among employers would ensure that most (but not all) workers receive shares of the pie roughly commensurate with their economic contribution. Such a labor market, however, may produce less than the optimal level of worker participation and voice, with lower wealth and well-being than is at least theoretically possible (Levine and Tyson, 1990; Freeman and Lazear, 1995; Kaufman and Levine, 2000).

The remainder of this section is speculative, attempting to outline a general direction in which we might head in order to enhance worker voice and participation, an outcome that Freeman and Medoff once envisioned being possible through the positive face of traditional labor unions. As previous discussion has indicated, I am skeptical that labor unions can provide the principal road to enhanced voice in the workplace. If enhanced individual voice and participation are to occur, they must develop using a variety of approaches in multiple types of largely nonunion workplaces. Successful approaches to enhanced voice are unlikely to be mandated from above. Rather, they are likely to evolve through experimentation and cooperation among employers and their workers, with successful forms being imitated throughout the economy. Organized

\footnotetext{
${ }^{24}$ For a description and data on what workers want, see Freeman and Rogers (1999). Kaufman (2001) provides a discussion and critique. Workers appear to desire individual voice and cooperation - not union voice per se.
} 
labor either will be reinvigorated and reinvented via competition - or will continue to whither.

I will not describe the specifics of what the future ought to look like. Rather, I first outline a set of criteria that workplace innovations should satisfy in order to evolve and flourish, followed by proposals that appear to satisfy these criteria. Whether beneficial changes (either those proposed here or elsewhere) can be identified and adopted via the political process is a different question, one about which I have little to say.

\section{Criteria for Value-Enhancing Reforms in the Workplace. ${ }^{25}$ A prerequisite for discussion of} workplace reforms is to identify criteria that labor and employment law changes should satisfy. I offer the following. Reforms should: (1) be value enhancing for the parties and the economy ${ }^{26}$; (2) involve a greater role for individual and group voice within nonunion and union workplaces; (3) should encourage cooperation and participation across and among all levels of workers; (4) allow for variation in workplace governance type across heterogeneous workplaces; (5) allow flexibility within workplaces over time; (6) limit rather than facilitate rent seeking among worker organizations, including but not limited to labor unions; and (7) facilitate the evolution of workplace agents and institutions that best represent workers' interests and rights (on this point, see Weil, 2003).

Absent major reforms and changes in current labor law, it is difficult to see how the current system can evolve toward adoption of employment governance structures embodying these characteristics. Meaningful change requires several things to occur. First, management must have incentives to initiate and encourage changes in workplace governance, changes that require removal of current legal barriers. Second, competitive pressures in product and labor markets are probably necessary. And third, pro-active changes in employment law and labor market regulations are likely necessary.

I discuss below two general approaches that have the potential to be value enhancing. The first approach is termed conditional deregulation. The second approach involves a change in the labor law default from no union to some alternative state. For each of these approaches, a move away from either the default regulatory structure or default governance structure within the firm requires approval of both management and workers (discussed below). The requirement for mutual agreement encourages

\footnotetext{
${ }^{25}$ These proposals follow discussion previously presented in Hirsch and Schumacher (2002).

${ }^{26}$ For change to be enhancing for the parties, the "value of the enterprise" must increase. Abowd (1989) defines the value of the enterprise as the sum of firm market value and worker rents.
} 
management and workers to develop value-enhancing alternatives to the default structure.

- Conditional Deregulation. Here I describe a variant of a proposal suggested by Levine (1995),

which he describes as conditional deregulation. Levine recognizes that there are a large number of governmental mandates and regulatory measures regarding workplace safety, hours and overtime requirements, pensions, discrimination, family leave, and the like. Under a system of conditional deregulation, the default for all (or nearly all) firms would be that they are covered by the full extent of these labor market regulations. These requirements would be divided into those that are non-waivable and those waivable. Non-waivable rights would include some minimum set of standards (say, with respect to discrimination or safety) that could not be waived by any employer. Conditional deregulation would permit employers to be exempt from the waivable set of regulatory standards and be subject only to the minimum standards if they voluntarily adopt alternative regulatory systems with employee oversight and approval.

In order to waive the regulations or "deregulate" workplace standards, firms must have in place independent worker committees to perform the approval and oversight functions. For union companies, the union would provide the employee voice with authority to waive government standards (the employer must also approve the waiver). For nonunion employers, worker committees or councils would be created with authority to approve the waiver on behalf of workers. A contentious issue would be the nature of these committees and the permissible employer role. Unlike Levine, I would argue for abolishment or major reform of 8(a)(2) of the NLRA, which restricts the creation of and role for worker associations other than traditional labor unions. (I would support abolishment of 8(a)(2) even absent other reforms.) I would permit a reasonably active role for the firm in setting up such worker councils, as long as the worker groups meet minimum requirements regarding independence, democratic choice of worker spokespersons, secret balloting on key issues, and antidiscrimination provisions protecting workers active in the worker associations. ${ }^{27}$

An important benefit of such an approach would be that it would spur the establishment of worker associations throughout the private sector and provide a vehicle to enhance worker voice and participation, and possibly cooperation between management and its workers. In those establishments where worker

\footnotetext{
${ }^{27}$ The TEAM Act, passed by Congress but vetoed by President Clinton in July 1996, would have limited the scope of 8 (a)(2) and allowed employer-organized and employer-funded worker participation groups in nonunion plants and offices. I support such legislation, whereas Levine would continue protections that prevent creation of "company unions." For evidence on how company unions worked prior to passage of the NLRA, see Kaufman (2000).
} 
associations are formed, its major role will likely be to facilitate the exchange of information and provide workers a collective voice. Such worker groups, however, may also serve as a vehicle to transfer rents or quasi-rents from shareholders to workers, since their approval of waiving workplace regulations is likely to be conditional on the receipt of monetary or non-monetary gains. Because the employer has the option of staying with the default regulatory standard, this makes it likely that any gains to workers through rent transfer will be less than the additional gains to shareholders from deregulation. In short, such a policy encourages value-enhancing choices by the firm and workers, while constraining the extent of rent seeking. Adoption of conditional deregulation, as outlined above, would likely accelerate Congressional passage of waivable labor market mandates and employment regulations. Moreover, such regulations would likely set more stringent standards and contain fewer exemptions (based on company size and the like) than in the past. More stringent regulations could be costly absent the option to waive coverage. Given the availability of an opt-out, however, those establishments where regulations would prove costly are the ones most likely to agree on a mutually-preferred set of alternative standards. The hope is that establishments will create workers' associations that gradually evolve into effective vehicles for voice, encouraging cooperation between management and its employees and facilitating value-enhancing changes in the workplace.

Conditional deregulation and the widespread creation of worker associations would have uncertain effects on unions. To the extent that nonunion worker associations substitute for traditional organizing, workers in some sectors may see even less reason to unionize. Just as likely an outcome is that conditional deregulation would provide the impetus for fundamental changes in and growth of labor unions in the private sector. With independent nonunion worker groups in place, workers in some firms will decide to turn to traditional collective bargaining and a more formalized union voice.

- Changing the Labor Law Default. A second proposed approach would shift the labor law default from its current setting of not unionized to some alternative invoking a governance structure providing independent worker voice. The default structure could be waived or replaced following the joint approval of workers and management. A point to emphasize is that the choice of the labor law and employment regulation defaults matter a lot, even where there exist procedures to modify those outcomes (Sunstein, 2001). For example, current labor law has a nonunion default, but allows majority worker choice of union 
representation. Imagine the opposite, with union representation the default, but workers free to reject representation by majority vote. In a frictionless system in which preferences are unaffected by the initial allocation, one might expect the two systems to produce the same outcomes. ${ }^{28}$

Obviously, eventual representation outcomes would differ enormously depending on a union versus a nonunion default. For one thing, the NLRA union certification and decertification processes are far from frictionless. Even absent such frictions, however, evidence from behavioral economics (Sunstein, 2001; Choi et al., 2003) indicates that workers would be more likely to stick to their initial endowment (collective bargaining) than would have chosen to adopt it through free elections. Were union coverage the workplace default, far more than 10 percent of private sector workers would remain unionized, even with frictionless decertification elections.

Why does the default affect outcomes? First, change is costly. Second, individuals exhibit behavioral inertia, often sticking with an existing rule or environment as long as it does not differ too much from the preferred choice. Third, and very important, is that the default signals a norm that the state (or employer, etc.) has deemed appropriate. That is, the choice of a norm affects individuals' evaluation of alternative arrangements. Whatever the relative importance of these reasons, a default governance structure must be chosen carefully since many workplaces will not change from it. ${ }^{29}$ That being said, the default is not a mandate, but a starting point or endowment (or bargaining "threat point") from which the parties can move.

What might be an appropriate labor law default other than the current nonunion default? My preference is for a default that establishes some form of independent worker association, although not one with full collective bargaining rights. As part of any default, workers would retain their current right to form independent unions (without management approval). An important feature of a default mechanism is that it designates a standard procedure by which workers and management might discuss, negotiate, and approve mutually beneficial changes. It would be important that $8(a)(2)$ of the NLRA be crippled or abolished. This

\footnotetext{
${ }^{28}$ In order to focus on the role of defaults, I assume that majority approval is synonymous with union coverage, ignoring the issue of obtaining a first contract following a union win.

${ }^{29}$ Choi et al. (2003) make the interesting point that where preferences are diverse and the firm (or state in our case) cannot readily identify a preferred default rule, it can make sense to assign a highly inefficient default, thus encouraging parties to select a preferred alternative. Where preferences are homogeneous and change is costly, it is important to choose a default close to the parties' preferred outcome. Choi et al. analyze pension contribution rules for workers within a firm. Our situation is more difficult, since a common governance structure is being assigned for workers within the firm who may have heterogeneous preferences.
} 
would permit and encourage management to be involved in the development of their firm's labor relations system, but with workers now starting from an enhanced endowment or bargaining position. Although one cannot predict precisely how any given system might evolve and operate, the widespread availability of the Internet makes it likely that both management and employee groups will use electronic communications to provide and exchange information (Diamond and Freeman, 2001; Freeman, 2002).

Note that the proposal for a change in the employment default can be combined with Levine's proposal for conditional deregulation. Assume that the selected default establishes a relatively independent worker association in the workplace. Management and workers could then make a joint decision to opt-out of waivable federal workplace standards.

Whatever default, it will not function well in all workplaces. The same is true for our current labor law default. In these workplaces, the employer and workers (either in the form of unions or worker associations) have incentive to move away from the default and develop proposals for participatory valueenhancing governance structures. Over time, operation of the system and the observed choices of workers and firms will produce legislated and administrative changes in the default. The inability to identify in advance all outcomes of a given reform should not necessarily be regarded as a serious criticism. The same can be said about any change - or the status quo. Laws and regulations do evolve over time.

The important point is that not only can workplaces opt out of the default, but the search for an alternative governance structure involves a productive exchange of information and the exercise of worker and management voice. Adoption of such a proposal should encourage management, workers, and workers' agents (be they traditional unions or worker associations) to communicate, negotiate, and arrive at alternatives that make all parties better off relative to the default. Clearly, the current labor law default provides little incentive for management or traditional unions to develop alternatives. An alternative default that permitted greater flexibility, be it through conditional deregulation or nonunion worker associations, would encourage value-enhancing innovations.

A major change in employment law and the default governance structure obviously requires 
thorough analysis and careful design. ${ }^{30}$ The actual working of such a system, however, will be determined in no small part by the way it evolves in the workplace, courts, and regulatory agencies. Surprises will occur. Unanticipated outcomes may be good or bad. One simply hopes (perhaps naively) that policy evolves to minimize undesirable and encourage desirable results. An important concern is that a shift in the default away from the nonunion standard toward one emphasizing collective voice might shift too much power to incumbent workers (insiders), leading to employer cost levels inconsistent with full employment. It may prove difficult to limit the ability of worker associations or works councils to appropriate rents within a framework that promotes voice and the evolution of value-enhancing arrangements (Freeman and Lazear, 1995). But it strikes me that it's worth a try.

I sensibly end this rather speculative section on a sober note. The most likely prospect for the future, or at least the near future, is not adoption of any proposal discussed above, but continuation of the status quo. Changing the status quo in employment law does not appear feasible. Major changes cannot occur politically until there is strong dissatisfaction with our current system and a consensus that change is likely beneficial. While such a consensus may exist among legal and industrial relations scholars, it does not exist among workers or the general public. The emergence of a consensus for major workplace changes could result from some future economic and social upheaval. Whether such an upheaval will occur, its form if it does so, and the nature of a new majority consensus are far beyond the scope of this paper - and my imagination.

An alternative scenario is that major changes in workplace governance will occur, but that they will occur incrementally, absent a major upheaval or a spur via major public policy changes. A premise of my discussion has been that there are potential gains from greater employee voice and worker participation. What is needed is a governance form or workplace arrangements to make these gains possible. If $8(a)(2)$ were abolished, one can imagine such arrangements gradually evolving, working well in some workplaces, and then being adopted elsewhere in various forms. The Internet will likely play a major role in any such evolution (Diamond and Freeman, 2001; Freeman, 2002). Labor unions, companies, and other workplace

\footnotetext{
${ }^{30}$ Relevant is the experience that other countries have had or will have with worker councils and alternative forms of organization, particularly in countries with relatively decentralized wage setting. The European Union Charter of Fundamental Rights of December 2000 provides for what appears to be broad-based guarantees for workers to have rights for information, consultation, and collective agreements (European Union, 2000, Articles 27, 28). How the Charter will be interpreted and implemented is unclear, but European experiences deriving from the Charter may well hold lessons for U.S. employment law reforms.
} 
organizations already use the Internet heavily to communicate with their members or workers. There are isolated examples (Walmart, IBM) where union-like worker voice groups, with little prospect for collective bargaining coverage, have emerged through the Internet, facilitating exchange of information and sometimes influencing company policies (Freeman, 2002). Employee voice is about communication and information, both of which are facilitated through electronic communication over networks. Whether effective nonunion employee voice and participation, coupled with an evolving and increasingly supportive legal and regulatory structure, will emerge, remains to be seen. Twenty years ago, Freeman and Medoff saw little need to address alternative nonunion forms for worker voice. Were What Do Unions Do? being written today, this is no doubt a subject the authors would consider.

\section{Conclusion}

A common characterization of What Do Unions Do?, one heard largely although not exclusively from outside the research community, is that Freeman and Medoff argue that unions are unambiguously good good for their members, good for economic performance, and good for society as a whole. Such a simplistic generalization about unions was inaccurate in 1984 and is still inaccurate today. But this is not what Freeman and Medoff say in What Do Unions Do? It is true that they tend to emphasize positive aspects of unionism. But this must be seen in context. A major and legitimate goal of What Do Unions Do? was to critique neoclassical economists for their then disproportionate focus on the "single face" monopoly aspects of labor unions. (Their challenge to industrial relations scholars has not been to broaden scope but to provide evidence.) They emphasize that there is a second and perhaps primary face of unions - the collective voice/institutional response face. What Do Unions Do? establishes that voice or nonmonopolistic aspects of unions should not be ignored and are worthy of serious analysis. Freeman and Medoff then provide a comprehensive empirical analysis of labor unions and interpret their findings in an intellectually honest

manner. A broader "multi-face" view of unionism became widely accepted following the book's publication in 1984, and this perspective remains widely accepted today. And the analysis summarized in What Do Unions Do? has served as a reference point and stimulant for much of the subsequent literature on unions, much of which is examined in this and other papers in this symposium.

How have the empirical findings summarized in What Do Unions Do? held up over time? For the 
most part, the empirical regularities that they identify as union effects have been sustained in subsequent research. I have focused on the chapters on unions and economic performance - productivity, investment, growth, and profitability. The subsequent literature has proven less favorable for unions than the conclusions reached by Freeman and Medoff. That being said, little literature existed at the time What Do Unions Do? was written and, even now, the empirical evidence in this area is (understandably) limited and cannot establish (or reject) causal union effects or their magnitudes nearly so conclusively as one might like. Freeman and Medoff are clearly correct that variation in union productivity effects vary substantially across workplaces. But their conclusion that union effects are generally positive, which I interpret to mean a nontrivial positive average effect, cannot be sustained, subsequent evidence suggesting an average union productivity effect near zero and at most modestly positive (say, 2-5 percent). Their speculation that productivity effects are larger in more competitive environments appears to hold up, but more evidence on this score would be desirable. Subsequent literature has continued to find unions associated with lower profits. Unlike Freeman and Medoff, several of the studies conclude that unions tax not just monopoly profits, but also the quasi-rents or long-run normal returns emanating from long-lived physical capital and R\&D. Lower profits and the union tax on tangible and intangible capital has led to slower employment and productivity growth among union companies, reinforcing the downward trend in private sector unionism. Although union firms grow more slowly, Freeman and Medoff appear correct that unions do not lead to higher rates of business failure.

Even adopting a positive view of the evidence on unions and performance, union effects have not been sufficient to offset what are large (by international standards) union wage premiums in the U.S. Because the voice face of unions depends so crucially on cooperative labor relations, management resistance to unionism and union organizing in the years since What Do Unions Do? has precluded any chance there might have been for this to be a period of expanding, cooperative, value-enhancing unionism. In short, the collective-voice face of unionism has been muted (or swamped) during the 20 years since publication of What Do Unions Do? One can argue as to how much of the management opposition is ideological, how much stems from the economic incentives of management to hold down costs in the face of union wage premiums and a highly competitive environment (Freeman and Kleiner, 1990), and how much is the result of 
labor law enforcement and generally low penalties (Kleiner, 2002). All three explanations clearly matter.

What Do Unions Do? has provided scholars and the public with a comprehensive and innovative documentation of the economic effects of unions. Yet whatever one's assessment of the evidence, old-style private sector unionism will continue to play a smaller and smaller role in the U.S. workplace. The publication date of What Do Unions Do? was doubly timely. It could not have appeared much sooner, given that the micro-level data sets on which much of the analysis is based had only recently become available. And although the empirical relationships uncovered by Freeman and Medoff look much the same today as twenty years ago, the focus of the book inevitably would have had to shift toward public sector unionism, alternatives to private sector unionism, or international comparisons (precisely the topics on which Freeman has subsequently focused). Labor economists and industrial relations scholars truly have been fortunate. Freeman and Medoff told us what private sector unions do while there remained unions doing it.

The research program ignited by What Do Unions Do? has continued apace as private sector unionism has declined. This program has been a rich one, extending beyond economists' earlier focus on monopoly unionism and union wage gaps and instead pursuing the ambitious agenda set by Freeman and Medoff. A principal concern among scholars has been the same concern made explicit in What Do Unions Do? How can we encourage value-enhancing workplace arrangements that facilitate voice among workers, while constraining unions' monopoly face? Freeman and Medoff focus their attention on traditional labor unionism. But with union density unlikely to rebound in the foreseeable future, the focus in recent literature is increasingly on the 90 percent of private sector workers without a formal mechanism for individual or collective voice and on new forms of workplace governance that might facilitate such voice.

I have provided some rather speculative ideas on the future of workplace voice. A likely path is that we will remain with something akin to the status quo, thus foregoing potential benefits from increased voice and participation. I have described new employment law defaults that might encourage the development of value-enhancing workplace governance structures - that is, those that make possible the benefits of voice with minimal rent seeking. "Radical" changes of this sort, however, appear politically impossible absent major social or political upheavals that economists have little ability to foresee (Freeman, 1998). A more likely avenue for change will be the gradual evolution of the workplace environment, employment law, and 
workplace governance in ways conducive to voice, participation, technological change (affecting what workers do), and the economic environments in which companies and households operate. There is of course no guarantee that the evolutionary changes produced in a competitive world will result in the type of arrangements described in the industrial relations literature. Nor can we envision what precise paths might be taken to effect such changes, although intensive Internet use for exchanging information, coordination of activities, and facilitating collective action appears likely. If future paths lead to workplace governance structures that take advantage of worker voice while restraining collective rent seeking, it will be in no small part a product of the productive discourse fueled by What Do Unions Do? 


\section{REFERENCES}

Abowd, John M. "The Effect of Wage Bargains on the Stock Market Value of the Firm." American Economic Review 79 (September 1989): 774-800.

and Henry S. Farber. "Job Queues and the Union Status of Workers." Industrial and Labor Relations Review 35 (April 1982): 354-67.

Addison, John T. and Clive R. Belfield. "Union Voice." In James T. Bennett and Bruce E. Kaufman, eds. What Do Unions Do? The Evidence Twenty Years Later, forthcoming.

Addison, John T. and John B. Chilton. "Self-Enforcing Union Contracts: Efficient Investment and Employment." Journal of Business 71 (July 1998): 349-69.

Addison, John T., John S. Heywood, and Xiangdong Wei. "New Evidence on Unions and Plant Closings: Britain in the 1990s." Southern Economic Journal 69 (April 2003): 822-41.

Addison, John T. and Barry T. Hirsch. "Union Effects on Productivity, Profits, and Growth: Has the Long Run Arrived?" Journal of Labor Economics 7 (January 1989): 72-105.

. "The Economic Effects of Employment Regulation: What Are the Limits?" In Bruce E. Kaufman, ed. Government Regulation of the Employment Relationship. Madison, Wisc.: Industrial Relations Research Association, 1997, pp. 125-78.

Addison, John T. and W. Stanley Siebert. "Recent Changes in the Industrial Relations Framework in the UK." In John T. Addison and Claus Schnabel, eds. International Handbook of Trade Unions. Northampton, Mass.: Edward Elgar, 2003, pp. 415-60.

Aidt, Toke and Zafiris Tzannatos. Unions and Collective Bargaining: Economic Effects in a Global Environment. Washington, D.C.: World Bank, 2002.

Allen, Steven G. "The Effect of Unionism on Productivity in Privately and Publicly Owned Hospitals and Nursing Homes." Journal of Labor Research 7 (Winter 1986a): 59-68.

. "Unionization and Productivity in Office Building and School Construction." Industrial and Labor Relations Review 39 (January 1986b): 187-201.

Ash, Michael and Jean Ann Seago. “Do Unionized Registered Nurses Reduce AMI Mortality?" University of Massachusetts, PERI Working Paper 28, 2002.

Baldwin, Carliss Y. "Productivity and Labor Unions: An Application of the Theory of Self-Enforcing Contracts." Journal of Business 56 (April 1983): 155-85.

Becker, Brian E. and Craig A. Olson. "Labor Relations and Firm Performance." In M. Kleiner, R. Block, M. Roomkin, and S. Salsburg, eds. Human Resources and the Performance of the Firm. Madison, Wisc.: Industrial Relations Research Association, 1987, pp. 43-86. . "Unionization and Firm Profits.” Industrial Relations 31 (Fall 1992): 395-415.

Belman, Dale. "Unions, The Quality of Labor Relations, and Firm Performance.” In Lawrence Mishel and Paula B. Voos, eds. Unions and Economic Competitiveness. Armonk, NY: M.E. Sharpe, 1992, pp. 41107.

Betts, Julian R., Cameron W. Odgers, and Michael K. Wilson. "The Effects of Unions on Research and Development: An Empirical Analysis Using Multi-Year Data." Canadian Journal of Economics 34 (August 2001): 785-806.

Black, Sandra E. and Lisa M. Lynch. "How to Compete: The Impact of Workplace Practices and Information Technology on Productivity." Review of Economics and Statistics 83 (August 2001): 434-45. 
Blanchflower, David G. and Alex Bryson. "Changes Over Time in Union Relative Wage Effects in the UK and the US Revisited." National Bureau of Economic Research Working Paper 9395, December 2002.

Blanchflower, David G. and Richard B. Freeman. "Unionism in the United States and Other Advanced OECD Countries." In M. Bognanno and M. Kleiner, eds. Labor Market Institutions and the Future Role of Unions. Cambridge, Mass.: Blackwell Publishers, 1992, pp. 56-79.

Booth, Alison L. The Economics of the Trade Union. Cambridge: Cambridge University Press, 1995.

Bratsberg, Bernt and James F. Ragan, Jr. "Changes in the Union Wage Premium by Industry." Industrial and Labor Relations Review 56 (October 2002): 65-83.

Bronars, Stephen G. and Donald R. Deere. "Union Representation Elections and Firm Profitability." Industrial Relations 29 (Winter 1990): 15-37.

. "Unionization, Incomplete Contracting, and Capital Investment." Journal of Business 66 (January 1993): 117-32.

and Joseph S. Tracy. "The Effects of Unions on Firm Behavior: An Empirical Analysis Using Firm-Level Data.” Industrial Relations 33 (October 1994): 426-51.

Brown, Charles and James Medoff. "Trade Unions in the Production Process." Journal of Political Economy 86 (June 1978): 355-78.

Byrne, Dennis, Hashem Dezhbakhsh, and Randall King. "Unions and Police Productivity: An Econometric Investigation." Industrial Relations 35 (October 1996): 566-84.

Cappelli, Peter and David Neumark. "Do 'High Performance' Work Practices Improve Establishment Level Outcomes?” Industrial and Labor Relations Review 54 (July 2001): 737-75.

Card, David. "The Effect of Unions on the Structure of Wages: A Longitudinal Analysis." Econometrica 64 (July 1996): 957-79.

Cavanaugh, Joseph K. “Asset Specific Investment and Unionized Labor.” Industrial Relations 37 (January 1998): $35-50$

Chappell, William F., Walter J. Mayer, and William F. Shughart II. "Union Rents and Market Structure Revisited." Journal of Labor Research 12 (Winter 1991): 35-46.

Choi, James J., David Laibson, Brigitte C. Madrian, and Andrew Metrick. "Optimal Defaults." American Economic Review 93 (May 2003): 180-85.

Clark, Kim B. "The Impact of Unionization on Productivity: A Case Study." Industrial and Labor Relations Review 33 (July 1980a): 451-69.

. "Unionization and Productivity: Micro-Econometric Evidence." Quarterly Journal of Economics 95 (December 1980b): 613-39.

. "Unionization and Firm Performance: The Impact on Profits, Growth, and Productivity." American Economic Review 74 (December 1984): 893-919.

Connolly, Robert A., Barry T. Hirsch, and Mark Hirschey. "Union Rent Seeking, Intangible Capital, and Market Value of the Firm." Review of Economics and Statistics 68 (November 1986): 567-77.

Diamond, Wayne J. and Richard B. Freeman. "Will Unionism Prosper in Cyber-Space? The Promise of the Internet for Employee Organization.” National Bureau of Economic Research Working Paper 8483, September 2001. 
DiNardo, John and David S. Lee. "The Impact of Unionization on Establishment Closure: A Regression Discontinuity Analysis of Representation Elections." National Bureau of Economic Research Working Paper 8993, June 2002.

Domowitz, Ian R., Glenn Hubbard, and Bruce C. Peterson. "The Intertemporal Stability of the ConcentrationMargins Relationship.” Journal of Industrial Economics 35 (September 1986): 13-34.

Doucouliagos, Christos and Patrice Laroche. "What Do Unions Do to Productivity? A Meta-Analysis." Industrial Relations 42 (October 2003): 650-91.

Dunne, Timothy and David A. Macpherson. "Unionism and Gross Employment Flows." Southern Economic Journal 60 (January 1994): 727-38.

Estreicher, Samuel. "Freedom of Contract and Labor Law Reform: Opening Up the Possibilities for ValueAdded Unionism." New York University Law Review 71 (June 1996): 827-49.

European Union. "Charter of Fundamental Rights of the European Union." Official Journal of the European Communities C 364 (December 2000): 1-22, at http://www.europarl.eu.int/charter/pdf/text_en.pdf.

Fallick, Bruce C. and Kevin A. Hassett. "Investment and Union Certification." Journal of Labor Economics 17 (July 1999): 570-82.

Farber, Henry S. “The Analysis of Union Behavior.” In Orley C. Ashenfelter and Richard Layard, eds. Handbook of Labor Economics, Vol. II. Amsterdam: Elsevier, 1986, pp. 1039-89.

and Bruce Western. "Accounting for the Decline of Unions in the Private Sector, 1973-1988." In James Bennett and Bruce Kaufman, eds. The Future of Private Sector Unionism in the United States. Armonk, N.Y.: M.E. Sharpe, 2002, pp. 28-58.

Freeman, Richard B. "The Exit-Voice Tradeoff in the Labor Market: Unionism, Job Tenure, Quits and Separations." Quarterly Journal of Economics 94 (June 1980): 643-74.

. "Longitudinal Analyses of the Effects of Trade Unions." Journal of Labor Economics 2 (January 1984): 1-26.

. "Is Declining Unionization of the U.S. Good, Bad, or Irrelevant?" In Lawrence Mishel and Paula B. Voos, eds. Unions and Economic Competitiveness. Armonk, N.Y.: M.E. Sharpe, 1991, pp. 143-69.

. "Spurts in Union Growth: Defining Moments and Social Processes." In Michael D.Bordo, Claudia Goldin and Eugene N. White, eds. The Defining Moment: The Great Depression and the American Economy in the Twentieth Century. Chicago: University of Chicago Press (NBER), 1998, pp. 265-96.

. "The Labor Market in the New Information Economy." National Bureau of Economic Research Working Paper 9254, October 2002.

and Morris M. Kleiner. "Employer Behavior in the Face of Union Organizing Drives." Industrial and Labor Relations Review 43 (April 1990): 351-65.

. "Do Unions Make Enterprises Insolvent?" Industrial and Labor Relations Review 52 (July 1999): $510-27$.

Freeman, Richard B. and Edward P. Lazear. "An Economic Analysis of Works Councils.” In Joel Rogers and Wolfgang Streeck, eds. Works Councils: Consultation, Representation, and Cooperation in Industrial Relations. Chicago: University of Chicago Press (NBER), 1995, pp. 27-50.

Freeman, Richard B. and James L. Medoff. “The Two Faces of Unionism.” Public Interest 57 (Fall 1979): 6993.

What Do Unions Do? New York: Basic Books, 1984. 
Freeman, Richard B. and Joel Rogers. What Workers Want. Ithaca, N.Y.: Cornell University Press, 1999.

Fuchs, Victor R., Alan B. Krueger and James M. Poterba. "Economists' Views about Parameters, Values, and Policies: Survey Results in Labor and Public Economics.” Journal of Economic Literature 36 (September 1998): 1387-425.

Grant, Darren. "A Comparison of the Cyclical Behavior of Union and Nonunion Wages in the United States." Journal of Human Resources 36 (Winter 2001): 31-57.

Grout, Paul A. "Investment and Wages in the Absence of Binding Contracts: A Nash Bargaining Approach." Econometrica 52 (March 1984): 449-60.

Hirsch, Barry T. “Trucking Regulation, Unionization, and Labor Earnings: 1973-1985.” Journal of Human Resources 23 (Summer 1988): 296-319.

. "Market Structure, Union Rent Seeking, and Firm Profitability." Economics Letters 32 (January 1990): 75-79.

. Labor Unions and the Economic Performance of U.S. Firms. Kalamazoo, Mich.: Upjohn Institute for Employment Research, 1991a.

. "Union Coverage and Profitability Among U.S. Firms." Review of Economics and Statistics 73 (February 1991b): 69-77.

. "Firm Investment Behavior and Collective Bargaining Strategy." In Mario F. Bognanno and Morris M. Kleiner, eds. Labor Market Institutions and the Future Role of Unions. Cambridge, Mass.: Blackwell Publishers, 1992, 95-121.

. "Unionization and Economic Performance: Evidence on Productivity, Profits, Investment, and Growth.” In Fazil Mihlar, ed. Unions and Right-to-Work Laws. Vancouver, B.C.: The Fraser Institute, 1997, pp. 35-70.

and John T. Addison. The Economic Analysis of Unions: New Approaches and Evidence. Boston: Allen \& Unwin, 1986.

Hirsch, Barry T. and Robert A. Connolly. "Do Unions Capture Monopoly Profits?” Industrial and Labor Relations Review 41 (October 1987): 118-36.

Hirsch, Barry T. and David A. Macpherson. "Earnings and Employment in Trucking: Deregulating a Naturally Competitive Industry.” In James Peoples, ed. Regulatory Reform and Labor Markets. Norwell, Mass.: Kluwer Academic Publishing, 1998, pp. 61-112.

. "Earnings, Rents, and Competition in the Airline Labor Market." Journal of Labor Economics 18 (January 2000): 125-55.

. "Union Membership and Coverage Database from the Current Population Survey: Note." Industrial and Labor Relations Review 56 (January 2003): 349-54, and accompanying data site http://www.unionstats.com/.

Hirsch, Barry T. and Barbara A. Morgan. "Shareholder Risk and Returns in Union and Nonunion Firms." Industrial and Labor Relations Review 47 (January 1994): 302-18.

Hirsch, Barry T. and Kislaya Prasad. "Wage-Employment Determination and a Union Tax on Capital: Can Theory and Evidence Be Reconciled?” Economics Letters 48 (April 1995): 61-71.

Hirsch, Barry T. and Edward J. Schumacher. "Unions, Wages, and Skills." Journal of Human Resources 33 (Winter 1998): 201-19. 
. "Private Sector Union Density and the Wage Premium: Past, Present, and Future." In James Bennett and Bruce Kaufman, eds. The Future of Private Sector Unionism in the United States. Armonk, N.Y.: M.E. Sharpe, 2002, pp. 92-128.

Hirsch, Barry T., Michael L. Wachter, and James W. Gillula. "Postal Service Compensation and the Comparability Standard." Research in Labor Economics 18 (1999): 243-79.

Ichniowski, Casey, Kathryn Shaw, and Giovanna Prennushi. "The Effects of Human Resource Management Practices on Productivity: A Study of Steel Finishing Lines.” American Economic Review 87 (June 1997): 291-313.

Karier, Thomas. "Unions and Monopoly Profits." Review of Economics and Statistics 67 (February 1985): 3442.

Katz, Harry C. and John Paul MacDuffie. "Collective Bargaining in the U.S. Auto Assembly Sector." In Paula B. Voos, ed. Contemporary Collective Bargaining in the Private Sector. Madison, Wisc.: Industrial Relations Research Association, 1994, pp. 181-224.

Kaufman, Bruce E. "Accomplishments and Shortcomings of Nonunion Employee Representation in the PreWagner Act Years: A Reassessment." In Bruce E. Kaufman, and Daphne Taras, eds. Nonunion Employee Representation: History, Contemporary Practice, and Policy. Armonk, N.Y.: M.E. Sharpe, 2000, pp. 21-60.

. "The Employee Participation/Representation Gap: An Assessment and Proposed Solution." University of Pennsylvania Journal of Labor and Employment Law 3 (Spring 2001): 491-550.

and David I. Levine. “An Economic Analysis of Employee Representation.” In Bruce E. Kaufman and Daphne Taras, eds. Nonunion Employee Representation: History, Contemporary Practice, and Policy. Armonk, N.Y.: M.E. Sharpe, 2000, pp. 149-75.

Kleiner, Morris. "Intensity of Management Resistance: Understanding the Decline of Unionization in the Private Sector." In James Bennett and Bruce Kaufman, eds. The Future of Private Sector Unionism in the United States. Armonk, N.Y.: M.E. Sharpe, 2002, pp. 292-316.

, Jonathan Leonard, and Adam Pilarski. "How Industrial Relations Affect Plant Performance: The Case of Commercial Aircraft Manufacturing." Industrial and Labor Relations Review 55 (January 2002): 195-219.

Kremer, Michael and Benjamin A. Olken. "A Biological Model of Unions." National Bureau of Economic Research Working Paper 8257, April 2001.

Krueger, Alan B. and Alexandre Mas. "Strikes, Scabs and Tread Separations: Labor Strife and the Production of Defective Bridgestone/Firestone Tires." National Bureau of Economic Research Working Paper 9524, March 2003.

Kuhn, Peter. "Unions and the Economy: What We Know; What We Should Know." Canadian Journal of Economics 31 (November 1998): 1033-56.

LaLonde, Robert J., Gérard Marschke, and Kenneth Troske. "Using Longitudinal Data on Establishments to Analyze the Effects of Union Organizing Campaigns in the United States." Annales d' Économie et de Statistique 41/42 (1996): 155-85.

Leonard, Jonathan S. "Unions and Employment Growth.” In Mario F. Bognanno and Morris M. Kleiner, eds. Labor Market Institutions and the Future Role of Unions. Cambridge, Mass.: Blackwell Publishers, 1992, pp. 80-94.

Levine, David I. Reinventing the Workplace: How Business and Employees Can Both Win. Washington, D.C.: Brookings Institution, 1995. 
and Laura D'Andrea Tyson. "Participation, Productivity, and the Firm's Environment." In Alan S. Blinder, ed. Paying for Productivity: A Look at the Evidence. Washington, D.C.: Brookings Institution, 1990, pp. 183-237.

Lewis, H. Gregg. Union Relative Wage Effects: A Survey. Chicago: University of Chicago Press, 1986.

Linneman, Peter D., Michael L. Wachter, and William H. Carter. "Evaluating the Evidence on Union Employment and Wages." Industrial and Labor Relations Review 44 (October 1990): 34-53.

Long, Richard J. "The Effect of Unionization on Employment Growth of Canadian Companies." Industrial and Labor Relations Review 46 (July 1993): 691-703.

Malkiel, Burton G. A Random Walk Down Wall Street, 8th edn. New York: Norton, 2003.

Manning, Alan. Monopsony in Motion: Imperfect Competition in Labor Markets. Princeton, N.J.: Princeton University Press, 2003.

Mas, Alexandre. "Labor Unrest, Fairness and the Quality of Production: Evidence from the Construction Equipment Resale Market." Princeton University, November 2002.

Menezes-Filho, Naercio, David Ulph, and John van Reenen. "R\&D and Unionism: Comparative Evidence from British Companies and Establishments." Industrial and Relations Review 52 (October 1998): 4563.

Menezes-Filho, Naercio and John van Reenen. "Unions and Innovation: A Survey of the Theory and Empirical Evidence." Center for Economic Policy Research, Discussion Paper 3792, January 2003.

Metcalf, David. "Unions and Productivity, Financial Performance and Investment: International Evidence." In John Addison and Claus Schnabel, eds. International Handbook of Trade Unions. Northampton, Mass.: Edward Elgar, 2003, pp. 118-71.

Mitchell, Merwin W. and Joe A. Stone. "Union Effects on Productivity: Evidence from Western Sawmills." Industrial and Labor Relations Review 46 (October 1992): 135-45.

Nickell, Stephen and Richard Layard. "Labor Market Institutions and Economic Performance." In Orley C. Ashenfelter and David Card, eds. Handbook of Labor Economics, Vol. 3C. Amsterdam: Elsevier, 1999, pp. 3029-84.

Odgers, Cameron W. and Julian R. Betts. "Do Unions Reduce Investment? Evidence from Canada." Industrial and Labor Relations Review 51 (October 1997): 18-36.

Olson, Craig A. and Brian E. Becker. "The Effects of the NLRA on Stockholder Wealth in the 1930s." Industrial and Labor Relations Review 44 (October 1990): 116-29.

Pencavel, John H. Labor Markets Under Trade Unionism: Employment, Wages, and Hours. Cambridge, Mass.: Basil Blackwell, 1991.

. "The Surprising Retreat of Union Britain.” National Bureau of Economic Research Working Paper 9564, March 2003.

Ravenscraft, David J. "Structure-Profit Relationships at the Line of Business and Industry Level." Review of Economics and Statistics 65 (February 1983): 22-31.

Register, Charles A. "Wages, Productivity, and Costs in Union and Nonunion Hospitals." Journal of Labor Research 9 (Fall 1988): 325-45.

Reynolds, Morgan O. "Trade Unions in the Production Process Reconsidered." Journal of Political Economy 94 (April 1986): 443-47. 
Ruback, Richard S. and Zimmerman, Martin B. "Unionization and Profitability: Evidence from the Capital Market.” Journal of Political Economy 92 (December 1984): 1134-57.

Salinger, Michael A. "Tobin's q, Unionization, and the Concentration-Profits Relationship." Rand Journal of Economics 15 (Summer 1984): 159-70.

Simons, Henry C. "Some Reflections on Syndicalism.” Journal of Political Economy 52 (March 1944): 1-25.

Sunstein, Cass R. "Human Behavior and the Law of Work.” Virginia Law Review 87 (April 2001): 205-76.

Turnbull, Peter. "What Do Unions Do Now?” Journal of Labor Research 24 (Summer 2003): 491-527.

Voos, Paula B. and Lawrence R. Mishel. "The Union Impact on Profits: Evidence from Industry Price-Cost Margin Data." Journal of Labor Economics 4 (January 1986): 105-33.

Weil, David. "Individual Rights and Collective Agents: The Role of Old and New Workplace Institutions in the Regulation of Labor Markets." National Bureau of Economic Research Working Paper 9565, March 2003.

Wessels, Walter J. "The Effects of Unions on Employment and Productivity: An Unresolved Contradiction." Journal of Labor Economics 3 (January 1985): 101-108.

. “Do Unionized Firms Hire Better Workers?” Economic Inquiry 32 (October 1994): 616-29.

White, Lawrence J. "Trends in Aggregate Concentration in the United States." Journal of Economic Perspectives 16 (Fall 2002): 137-60. 


\section{IZA Discussion Papers}

\begin{tabular}{|c|c|c|c|c|}
\hline No. & Author(s) & Title & Area & Date \\
\hline 878 & $\begin{array}{l}\text { J. T. Addison } \\
\text { C. Schnabel } \\
\text { J. Wagner }\end{array}$ & $\begin{array}{l}\text { The Course of Research into the Economic } \\
\text { Consequences of German Works Councils }\end{array}$ & 3 & 09/03 \\
\hline 879 & $\begin{array}{l}\text { A. Constant } \\
\text { Y. Shachmurove }\end{array}$ & $\begin{array}{l}\text { Entrepreneurial Ventures and Wage Differentials } \\
\text { Between Germans and Immigrants }\end{array}$ & 1 & 09/03 \\
\hline 880 & $\begin{array}{l}\text { W. Koeniger } \\
\text { A. Vindigni }\end{array}$ & $\begin{array}{l}\text { Employment Protection and Product Market } \\
\text { Regulation }\end{array}$ & 2 & $10 / 03$ \\
\hline 881 & R. A. Hart & $\begin{array}{l}\text { Worker-Job Matches, Job Mobility, and Real } \\
\text { Wage Cyclicality }\end{array}$ & 1 & $10 / 03$ \\
\hline 882 & $\begin{array}{l}\text { A. Lindbeck } \\
\text { D. J. Snower }\end{array}$ & The Firm as a Pool of Factor Complementarities & 5 & $10 / 03$ \\
\hline 883 & $\begin{array}{l}\text { S. Groeneveld } \\
\text { J. Hartog }\end{array}$ & $\begin{array}{l}\text { Overeducation, Wages and Promotions within } \\
\text { the Firm }\end{array}$ & 5 & $10 / 03$ \\
\hline 884 & $\begin{array}{l}\text { J. Masso } \\
\text { A. Heshmati }\end{array}$ & $\begin{array}{l}\text { The Optimality and Overuse of Labour in } \\
\text { Estonian Manufacturing Enterprises }\end{array}$ & 4 & $10 / 03$ \\
\hline 885 & $\begin{array}{l}\text { A. Constant } \\
\text { K. F. Zimmermann }\end{array}$ & $\begin{array}{l}\text { The Dynamics of Repeat Migration: A Markov } \\
\text { Chain Analysis }\end{array}$ & 1 & $10 / 03$ \\
\hline 886 & $\begin{array}{l}\text { J. J. Dolado } \\
\text { M. Jansen } \\
\text { J. F. Jimeno }\end{array}$ & $\begin{array}{l}\text { On-the-Job Search in a Matching Model with } \\
\text { Heterogenous Jobs and Workers }\end{array}$ & 1 & $10 / 03$ \\
\hline 887 & $\begin{array}{l}\text { B. Irlenbusch } \\
\text { D. Sliwka }\end{array}$ & $\begin{array}{l}\text { Transparency and Reciprocal Behavior in } \\
\text { Employment Relations }\end{array}$ & 7 & $10 / 03$ \\
\hline 888 & W. Koeniger & $\begin{array}{l}\text { Collective Dismissal Cost, Product Market } \\
\text { Competition and Innovation }\end{array}$ & 3 & $10 / 03$ \\
\hline 889 & D. E. Wildasin & $\begin{array}{l}\text { Fiscal Policy, Human Capital, and Canada-US } \\
\text { Labor Market Integration }\end{array}$ & 2 & $10 / 03$ \\
\hline 890 & $\begin{array}{l}\text { M. Bratti } \\
\text { L. Mancini }\end{array}$ & $\begin{array}{l}\text { Differences in Early Occupational Earnings of } \\
\text { UK Male Graduates by Degree Subject: } \\
\text { Evidence from the 1980-1993 USR }\end{array}$ & 6 & $10 / 03$ \\
\hline 891 & $\begin{array}{l}\text { L. Flood } \\
\text { E. Pylkkänen } \\
\text { R. Wahlberg }\end{array}$ & $\begin{array}{l}\text { From Welfare to Work: Evaluating a Proposed } \\
\text { Tax and Benefit Reform Targeted at Single } \\
\text { Mothers in Sweden }\end{array}$ & 6 & $10 / 03$ \\
\hline 892 & B. T. Hirsch & What Do Unions Do for Economic Performance? & 5 & $10 / 03$ \\
\hline
\end{tabular}

An updated list of IZA Discussion Papers is available on the center's homepage www.iza.org. 